\title{
Thermokarst lake methanogenesis along a complete talik profile
}

\author{
J. K. Heslop ${ }^{1}$, K. M. Walter Anthony ${ }^{1}$, A. Sepulveda-Jauregui ${ }^{1}$, K. Martinez-Cruz ${ }^{1,2}$, A. Bondurant ${ }^{1}$, G. Grosse ${ }^{3, a}$, \\ and M. C. Jones ${ }^{4}$ \\ ${ }^{1}$ Water and Environmental Research Center, University of Alaska, Fairbanks, Alaska, USA \\ ${ }^{2}$ Biotechnology and Bioengineering, Cinvestav, Mexico City, Mexico \\ ${ }^{3}$ Geophysical Institute, University of Alaska, Fairbanks, Alaska, USA \\ ${ }^{4}$ US Geological Survey, Reston, Virginia, USA \\ anow at: Alfred Wegener Institute, Helmholtz Centre for Polar and Marine Research, Potsdam, Germany
}

Correspondence to: J. K. Heslop (jheslop@alaska.edu)

Received: 21 February 2015 - Published in Biogeosciences Discuss.: 24 March 2015

Accepted: 1 July 2015 - Published: 24 July 2015

\begin{abstract}
Thermokarst (thaw) lakes emit methane $\left(\mathrm{CH}_{4}\right)$ to the atmosphere formed from thawed permafrost organic matter $(\mathrm{OM})$, but the relative magnitude of $\mathrm{CH}_{4}$ production in surface lake sediments vs. deeper thawed permafrost horizons is not well understood. We assessed anaerobic $\mathrm{CH}_{4}$ production potentials from various depths along a $590 \mathrm{~cm}$ long lake sediment core that captured the entire sediment package of the talik (thaw bulb) beneath the center of an interior Alaska thermokarst lake, Vault Lake, and the top $40 \mathrm{~cm}$ of thawing permafrost beneath the talik. We also studied the adjacent Vault Creek permafrost tunnel that extends through ice-rich yedoma permafrost soils surrounding the lake and into underlying gravel. Our results showed $\mathrm{CH}_{4}$ production potentials were highest in the organic-rich surface lake sediments, which were $151 \mathrm{~cm}$ thick (mean $\pm \mathrm{SD}$ : $5.95 \pm 1.67 \mu \mathrm{g} \mathrm{C}-$ $\left.\mathrm{CH}_{4} \mathrm{~g} \mathrm{dw}^{-1} \mathrm{~d}^{-1} ; 125.9 \pm 36.2 \mu \mathrm{g} \mathrm{C}-\mathrm{CH}_{4} \mathrm{~g} \mathrm{C}_{\text {org }}^{-1} \mathrm{~d}^{-1}\right)$. High $\mathrm{CH}_{4}$ production potentials were also observed in recently thawed permafrost $\left(1.18 \pm 0.61 \mu \mathrm{g} \mathrm{C}-\mathrm{CH}_{4} \mathrm{~g} \mathrm{dw}^{-1} \mathrm{~d}^{-1}\right.$; $\left.59.60 \pm 51.5 \mu \mathrm{g} \mathrm{C}-\mathrm{CH}_{4} \mathrm{~g} \mathrm{C}_{\text {org }}^{-1} \mathrm{~d}^{-1}\right)$ at the bottom of the talik, but the narrow thicknesses $(43 \mathrm{~cm})$ of this horizon limited its overall contribution to total sediment column $\mathrm{CH}_{4}$ production in the core. Lower rates of $\mathrm{CH}_{4}$ production were observed in sediment horizons representing permafrost that has been thawing in the talik for a longer period of time. $\mathrm{No} \mathrm{CH}_{4}$ production was observed in samples obtained from the permafrost tunnel, a non-lake environment. Our findings imply that $\mathrm{CH}_{4}$ production is highly variable in thermokarst lake systems and that both modern OM supplied to surface sediments and ancient OM supplied to both surface and deep
\end{abstract}

lake sediments by in situ thaw and shore erosion of yedoma permafrost are important to lake $\mathrm{CH}_{4}$ production.

\section{Introduction}

Permafrost contains an estimated $1140-1476$ Pg of soil organic carbon (OC; Hugelius et al., 2014). It is considered to be a vulnerable carbon (C) pool in a warming climate (Schaefer et al., 2014; Schuur and Abbott, 2011), as both models and observations indicate that permafrost is warming and thawing in many regions (Romanovsky et al., 2010). Large uncertainties remain about the magnitude, timing, and form of $\mathrm{C}$ loss to the atmosphere from thawing permafrost; however, some studies suggest thawing permafrost will release 19-208 Pg C by 2050 (Schuur et al., 2013; Harden et al., 2012). A substantial portion $(\sim 450 \mathrm{Pg})$ of the deep permafrost $\mathrm{C}$ pool is stored in permafrost soils of the yedoma region, both in undisturbed yedoma and in the organic-rich sediments of thermokarst lake basins in the yedoma region (Walter Anthony et al., 2014). Yedoma refers to the icy latePleistocene loess-dominated permafrost soil type that occurs predominantly in previously unglaciated lowland regions of Beringia (NE Siberia, Alaska, and NW Canada; Grosse et al., 2013b; Zimov et al., 2006). Typical yedoma deposits in Alaska are $10-30 \mathrm{~m}$ thick, but can reach local thicknesses greater than $60 \mathrm{~m}$ (Pewe, 1975). Late Pleistocene yedoma ice wedges range from 2 to $6 \mathrm{~m}$ in width and can extend tens of meters below the ground surface (Kanevskiy et al., 2011). In addition to being ice-rich, the OC content of yedoma is 
high (2-5\%) for mineral soils (Walter Anthony et al., 2014; Strauss et al., 2013; Schirrmeister et al., 2011; Kholodov et al., 2003), and yedoma soils typically contain OC contents 10-30 times higher than that of similar loess-dominated nonpermafrost soils (Zimov et al., 2006).

In a warming climate, or when subjected to ground-surface disturbance, ice-rich yedoma is prone to thermokarst lake formation, a process by which the melting of massive ground ice forms depressions that fill with water (Soloviev, 1973). In yedoma-dominated regions, up to $90 \%$ of all lakes are thermokarst lakes (Pienitz et al., 2008). Thermokarst lakes strongly alter the local thermal balance of the land surface and transfer heat from the water body into the underlying ground more effectively than other land cover types (Grosse et al., 2013a; Burn, 2005), especially when the depth of a lake exceeds the thickness of the winter lake ice. The enhanced heat flux triggers rapid permafrost thaw and talik (thaw bulb) formation underneath the lake (Plug and West, 2009), which can lead to the mobilization of freshly thawed OC from yedoma (Kessler et al., 2012).

As permafrost thaws, it releases previously frozen OC, which can subsequently be processed by microorganisms that produce methane $\left(\mathrm{CH}_{4}\right)$ and carbon dioxide $\left(\mathrm{CO}_{2}\right)$. It is estimated that arctic systems annually emit $15-50 \mathrm{Tg}$ of $\mathrm{CH}_{4}$ (McGuire et al., 2009), a potent greenhouse gas which has 34 times more global warming potential than $\mathrm{CO}_{2}$ over a 100 year time period (Myhre et al., 2013). Many lakes formed in permafrost-dominated landscapes, particularly yedomatype thermokarst lakes, have high rates of $\mathrm{CH}_{4}$ emission (Sepulveda-Jauregui et al., 2015; Walter et al., 2007). The $\mathrm{CH}_{4}$ emitted from arctic lakes largely originates in terrestrial sources such as the Holocene soils of the lakes' watersheds (Kling and Kipphut, 1991), the thaw of Holoceneand Pleistocene-aged permafrost soil beneath and surrounding the lakes (Walter Anthony and Anthony, 2013; Brosius et al., 2012; Walter et al., 2008; Zimov et al., 1997), and decomposition of contemporary organic matter (OM) in the lakes (Walter Anthony et al., 2014).

The location of $\mathrm{CH}_{4}$ production in thermokarst lake systems is not well understood. Using radiocarbon dating, stable isotopes, and spatial mapping of $\mathrm{CH}_{4}$ emissions within lakes, Walter et al. (2006) concluded that the highest rates of $\mathrm{CH}_{4}$ emission occur along thermokarst margins, originating from actively expanding taliks. Numerical modeling of $\mathrm{CH}_{4}$ production in thermokarst lakes confirmed field-based observations that $\mathrm{CH}_{4}$ production is concentrated along permafrost thaw margins of lakes (Kessler et al., 2012). Surface lake sediments contain contemporary OM as well as re-deposited, thawed permafrost OM. Both sources may fuel $\mathrm{CH}_{4}$ production. At greater sediment depths, permafrost thaw in taliks under thermokarst lakes also supplies substrate for methanogenesis. However, the labile fraction of thawed permafrost $\mathrm{OM}$ is in limited supply so, given enough time, $\mathrm{CH}_{4}$ production in thawed permafrost sediments can diminish (Walter Anthony et al., 2014; Kessler et al., 2012).
The objective of this study was to constrain the location and magnitude of $\mathrm{CH}_{4}$ production in a thermokarst lake environment. We conducted long-term anaerobic incubations using sediment samples collected from a deep thermokarst lake core in the center of the lake that extended from the sediment surface, through the talik, and into the yedoma permafrost underlying the talik. We compared $\mathrm{CH}_{4}$ production rates from the lake core to those of samples collected from an adjacent permafrost tunnel, which extended through yedoma deposits into the underlying gravel. We also measured the thickness of the talik at various locations in the lake to help constrain the spatial variability of $\mathrm{CH}_{4}$ production in the lake.

\section{Methods}

\subsection{Study site}

The Vault Creek permafrost tunnel and Vault Lake (informal name; $65.0293^{\circ} \mathrm{N}, 147.6987^{\circ} \mathrm{W}$ ) are located approximately $40 \mathrm{~km}$ north of Fairbanks, Alaska, USA, in a region characterized by discontinuous permafrost (Fig. 1). The region experiences a continental climate with a mean annual air temperature of $-2.39^{\circ} \mathrm{C}$ and $274.6 \mathrm{~mm}$ mean annual precipitation (Fairbanks International Airport 1981-2010, National Climate Data Center). The $220 \mathrm{~m}$ long Vault Creek permafrost tunnel, previously described by Meyer et al. (2008), extends through a $25 \mathrm{~m}$ thick yedoma sequence and a $15 \mathrm{~m}$ thick gravel horizon down to bedrock. The tunnel entrance is secured by a steel tube, making the top $8 \mathrm{~m}$ of the profile inaccessible to sampling. Vault Lake $\left(3200 \mathrm{~m}^{2}, 4.6 \mathrm{~m}\right.$ maximum depth, $3.7 \mathrm{~m}$ average depth; Walter Anthony, unpublished data), located within $60 \mathrm{~m}$ of the subsurface tunnel, is a first-generation thermokarst lake formed by the melting of permafrost ground ice, including massive ice wedges. Steep, eroding bluffs, tilted spruce trees along the margins, and numerous $\mathrm{CH}_{4}$ bubbling seeps across the lake surface indicate that the lake is still actively deepening and laterally expanding.

We measured lake and talik depth in March 2013 by drilling boreholes through thawed sediments to the permafrost table at six points along a transect spanning the long axis of the lake and at eight additional points distributed across the lake. Lake area and thermokarst bank height were measured by differential GPS (Leica Viva GS15, Leica Geosystems, Norcross, Georgia, USA) in November 2013. Talik temperatures were measured in galvanized steel tubes placed in two boreholes, one near the center of the lake (borehole (BH) 13) and the other $6.1 \mathrm{~m}$ from an actively expanding thermokarst margin (BH10). We installed temperature sensors (Onset TMCx-HD, accuracy $\pm 0.21^{\circ} \mathrm{C}$, Onset Corporation, Bourne, Massachusetts, USA) at four depths below the sediment-water interface within the talik (BH10: 0.5, 1.0, 6.2 , and $8.85 \mathrm{~m}$; BH13: $0.5,1.0,5.7$, and $6.2 \mathrm{~m}$ ). With the ex- 

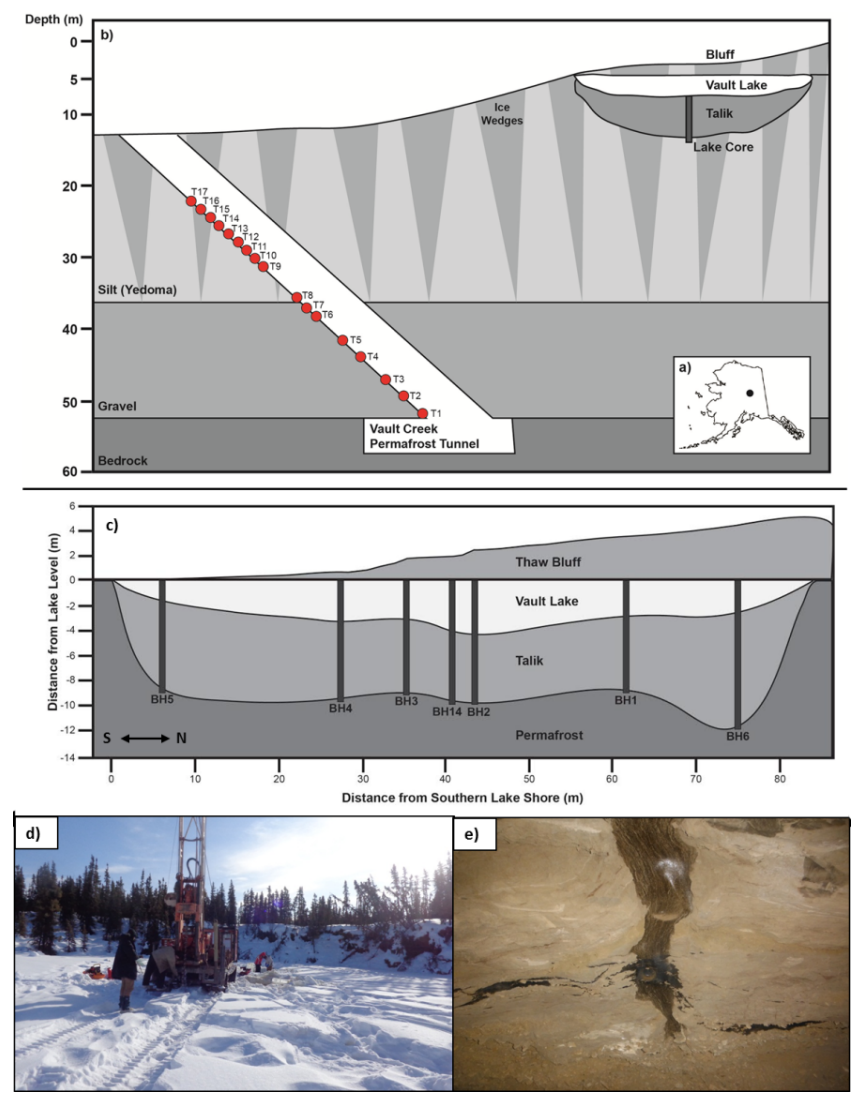

Figure 1. Location map (a), study site overview (b), and Vault Lake morphology shown in cross section along the long axis of the lake (c) for Vault Lake and Vault Creek permafrost tunnel, Alaska, USA $\left(65.0293^{\circ} \mathrm{N}, 147.6987^{\circ} \mathrm{W}\right)$. Height of the thaw bluffs was measured using differential GPS (DGPS). Depth of the Vault Lake talik was measured using the delineated borehole transect (c). Thaw bluff heights, lake depth, talik depths, and distance between boreholes $(\mathbf{b}, \mathbf{c})$ are shown to scale. Vault Lake is a $3230 \mathrm{~m}^{2}, 3.7 \mathrm{~m}$ deep thermokarst lake with thermokarst bluffs (d) ranging from 0.2 to $4.5 \mathrm{~m}$ in height and a $5.9 \mathrm{~m}$ deep talik underneath. The Vault Lake core was collected from the center of the lake (BH14). The Vault Creek permafrost tunnel extends 220 to $40 \mathrm{~m}$ depth below the ground surface. Ice wedges (e) are present to $23 \mathrm{~m}$ depth. Tunnel sampling sites are marked as red dots; numbers adjacent to the dots represent incubation sample IDs. Photographs by K. M. Walter Anthony (d) and J. K. Heslop (e).

ception of a missing-data period between 25 July 2014 and 11 November 2014, temperatures were recorded hourly from May 2013 through December 2014.

\subsection{Sediment sample collection, preparation, and characterization}

During March 2013, a $590 \mathrm{~cm}$ long sediment core was collected from the center of Vault Lake (BH14, $4.0 \mathrm{~m}$ water depth). Using a Boart Longyear diamond core drilling system, continuous sediment cores were retrieved by percussion coring with a split spoon sampler. Sediment core sections were retrieved in $6 \mathrm{~cm}$ diameter clear plastic liners inside of core barrels in approximately $60 \mathrm{~cm}$ intervals from the same hole. Casing inside the hole ensured that adjacent sediments did not slough. The sediment core captured nearly the entire sequence of thawed lake sediments in the talik $(550 \mathrm{~cm})$ and the top $40 \mathrm{~cm}$ of permafrost beneath the talik, though several short sections of core were lost from tubes during retrieval (Fig. 2). Thawed core sections were sealed and stored in the laboratory at $3{ }^{\circ} \mathrm{C}$. The permafrost section was sealed and stored in the laboratory at $-10^{\circ} \mathrm{C}$.

We measured magnetic susceptibility on the intact Vault Lake core using a loop sensor on an automated core logger (Geotek MSCL-X, Geotek Limited, Daventry, Northamptonshire, United Kingdom) at the Limnological Research Center Core (LacCore) Facility in the University of Minnesota, Minneapolis, Minnesota, USA. Then we split the core lengthwise and immediately sealed and archived one half of the core at $3{ }^{\circ} \mathrm{C}$ for later use in anaerobic incubations. This first half of the core was sealed with four layers of oxygen- $\left(\mathrm{O}_{2}\right)$ and moisture-barrier film (Krehalon PC101, Filcon, Clare, Michigan, USA).

On the second half of the core, we conducted initial core descriptions and made the following measurements at LacCore. We imaged the core using a line scan camera (Geotek Geoscan-III, Geotek Limited, Daventry, Northamptonshire, United Kingdom). High-resolution magnetic susceptibility was measured in $0.5 \mathrm{~cm}$ intervals using a point sensor on an automated core logger (Geotek MSCL-XYZ, Geotek Limited, Daventry, Northamptonshire, United Kingdom). We sampled sediments in $10 \mathrm{~cm}$ intervals along the core at a known volume $\left(3 \mathrm{~cm}^{3}\right)$. We weighed samples at field moisture, then dried them at $105^{\circ} \mathrm{C}$ for $48 \mathrm{~h}$ and reweighed them to determine the weight loss compared to the total weight of the wet sample (gravimetric water content) and dry sediment weight per unit volume (dry bulk density). Smear slides were created from samples taken every $10 \mathrm{~cm}$ along the core and analyzed under a microscope to quantify the relative abundance of organic and mineral matter, sponge spicules, and diatoms.

We quantified plant macrofossils in a subset of lake sediment core samples (Table S1 in the Supplement). Macrofossil samples were sieved using a $250 \mu \mathrm{m}$ sieve, and the remaining plant material was examined in a petri dish in a slurry with deionized water using a binocular microscope. Relative percentages of each macrofossil type were calculated for each sample. Any macrofossils worth noting (seeds, leaves, needles, etc.) that did not comprise a large enough fraction of the sample were counted separately and simply noted as present.

In addition to the lake sediment core, triplicate samples of permafrost soils exposed in the Vault Creek tunnel adjacent to the lake were collected using a $75 \mathrm{~cm}^{3}$ hole saw mounted on a hand-held hammer drill from 16 distributed depths along the tunnel walls. The sediment samples repre- 


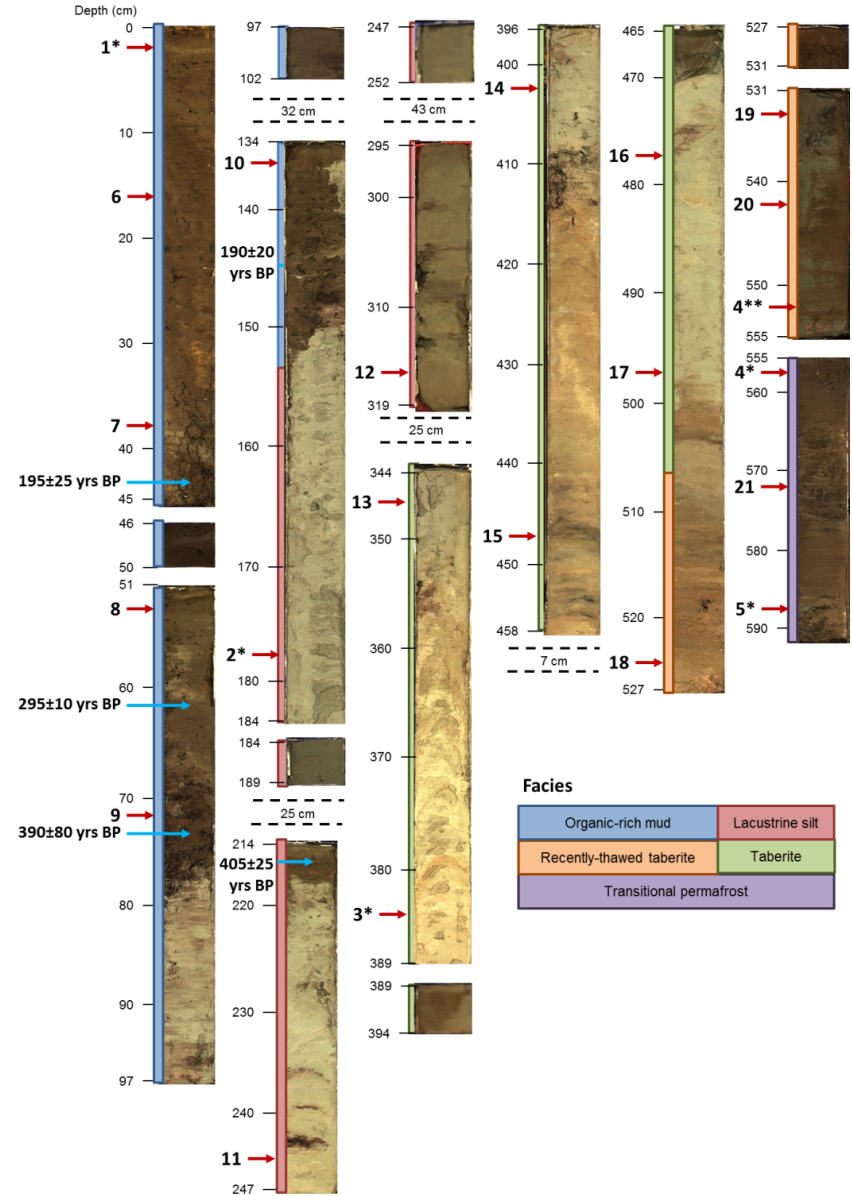

Figure 2. The Vault Lake core with the five facies (Organic-rich mud, Lacustrine silt, Taberite, Recently thawed taberite, and Transitional permafrost) delineated. Core depth values are indicated; core subsampling locations for incubations are marked using red arrows with bold numbers indicating incubation sample IDs; locations of picked and ${ }^{14} \mathrm{C}$ dated macrofossil are shown by blue arrows and calibrated ${ }^{14} \mathrm{C}$ ages (calendar years BP). Labeled breaks represent gaps in the sediment core.

sented the accessible profile from 9 to $40 \mathrm{~m}$ vertical depth beneath the ground surface. Permafrost samples were collected from both the yedoma horizon and the silty matrix of the underlying gravel horizon. Permafrost samples were stored in the laboratory at $-10^{\circ} \mathrm{C}$ until further analyses.

\subsection{Sediment facies classification}

Using the imagery, smear slides, macrofossil data, and our knowledge of thermokarst lake sediment facies classification based on Murton (1996), Walter Anthony et al. (2014), and Farquharson et al. (2015), we classified the Vault Lake core into five facies for subsampling: Organic-rich mud, Lacustrine silt, Taberite, Recently thawed taberite, and Transitional permafrost (Fig. 2).
Organic-rich mud consisted of the top $152 \mathrm{~cm}$ thick section of the lake core containing alternating layers of dark, organic-rich sediments, some peaty layers with variable sized plant debris, and lighter, mineral silt dominated layers. Smear slides and macrofossil analyses revealed relatively higher abundances of aquatic and terrestrial macrofossils indicative of the thermokarst-affected late-Holocene black spruce ecosystem with peaty, organic rich soil that is still observed around the lake today. Aquatic indicators included spicules, diatoms, Daphnia ephippia, and benthic mosses. Terrestrial macrofossils included mosses (Aulacomnium palustre, Sphagnum spp., Tomenthypnum nitens, Polytrichum spp.), and roots and leaves of ericaceous shrubs, and spruce (Picea spp.) needles (Table S1).

The Lacustrine silt facies, $178 \mathrm{~cm}$ thick $(153-330 \mathrm{~cm})$ and underlying the Organic-rich mud, consisted of massive mineral sediment with occasional peat balls, representing material that sloughed off exposed thermokarst margins of the lake. Since sediments of Lacustrine silt were exposed to the lake water column during erosion and re-deposition, they contained some, albeit fewer, aquatic indicators (spicules, diatoms, and Daphnia ephippia). Few other macrofossils were found in the silt-dominated matrix. These were primarily undifferentiated organic detritus with a few fragments of terrestrial mosses, bark, and ericaceous rootlets.

Taberite sediments $(331-550 \mathrm{~cm})$, representing yedoma sediment which thawed in situ and remained underneath the lake (Walter Anthony et al., 2014; Schirrmeister et al., 2011), were identified as massive, mostly mineral (silt)-dominated sediments. We did not find diatoms or any other aquatic indicators in this facies. The little OM that was present was dominated by fine, indistinguishable detritus. The bottom $43 \mathrm{~cm}$ of the taberite $(508-550 \mathrm{~cm})$, representing the most recently thawed sediments, was designated as Recently thawed taberite.

Beneath the thawed portion of the lake core, we sampled $40 \mathrm{~cm}$ of transitional permafrost $(551-590 \mathrm{~cm})$, which is close to the thaw transition with a large amount of unfrozen water in the inter-pore space but with numerous small lenses of bulk ice still present (Williams and Smith, 1989). The Transitional permafrost section of our core was icebearing, silt-dominated soil with few organic remains, identified as graminoid detritus indicative of the cold, dry Pleistocene steppe ecosystem.

\subsection{Lake age}

We estimated the age of Vault Lake by obtaining accelerator mass spectrometry (AMS) radiocarbon dates on terrestrial plant macrofossils picked from the lake center sediment core. Samples were analyzed at the National Ocean Sciences AMS (NOSAMS) facility (Table 1). All radiocarbon ages were calibrated to calendar $2 \sigma$ years before present (BP) using Calib 7.0 (Reimer et al., 2013). 
Table 1. Radiocarbon ages of macrofossils picked from the Vault Lake sediment core, calibrated to calendar $2 \sigma$ years before present (BP) using Calib 7.0 (Reimer et al., 2013).

\begin{tabular}{|c|c|c|c|c|c|c|}
\hline $\begin{array}{r}\text { Depth in } \\
\text { core } \\
(\mathrm{cm})\end{array}$ & Lab ID & $\begin{array}{r}\text { NOSAMS } \\
\text { ID }\end{array}$ & $\begin{array}{l}{ }^{14} \mathrm{C} \text { age } \\
(\mathrm{yr} \mathrm{BP})\end{array}$ & $\begin{array}{r}\text { Calibrated age } \\
\text { (cal yr BP) }\end{array}$ & $\begin{array}{r}\text { Average age } \\
(\text { cal yr BP })\end{array}$ & Material dated \\
\hline 45 & $\begin{array}{l}\text { VAULT13-14A-1G-1-W } \\
48-50 \mathrm{~cm}\end{array}$ & 122576 & $150 \pm 25$ & $172-223$ & 195 & $\begin{array}{l}\text { Bryophyte } \\
\text { (Aulacomnium palustre) }\end{array}$ \\
\hline 62 & $\begin{array}{l}\text { VAULT13-14A-3N-1-W } \\
10.5-12.5 \mathrm{~cm}\end{array}$ & 122577 & $240 \pm 20$ & $285-303$ & 295 & $\begin{array}{l}\text { Bryophyte } \\
\text { (Aulacomnium palustre), } \\
\text { leaf fragments from ericaceous } \\
\text { shrubs or Betula nana, } \\
\text { Picea } \text { needles }\end{array}$ \\
\hline 72 & $\begin{array}{l}\text { VAULT13-14A-3N-1-W } \\
20.5-22.5 \mathrm{~cm}\end{array}$ & 122578 & $320 \pm 30$ & $356-432$ & 394 & $\begin{array}{l}\text { Bryophyte } \\
\text { (Aulacomnium palustre) }\end{array}$ \\
\hline 144 & $\begin{array}{l}\text { VAULT13-14A-4N-1-W } \\
8-19 \mathrm{~cm}\end{array}$ & 122579 & $170 \pm 20$ & $170-214$ & 190 & $\begin{array}{l}\text { Bryophyte } \\
\text { (Aulacomnium palustre), } \\
\text { leaf fragments from ericaceous } \\
\text { shrubs or Betula nana, } \\
\text { Picea } \text { needles }\end{array}$ \\
\hline 214 & $\begin{array}{l}\text { VAULT13-6N-1-W } \\
1-3 \mathrm{~cm}\end{array}$ & 122580 & $315 \pm 20$ & $375-429$ & 405 & $\begin{array}{l}\text { Leaf fragments from ericaceous } \\
\text { shrubs or Betula nana }\end{array}$ \\
\hline
\end{tabular}

\subsection{Geochemical analyses}

Sediment samples $\left(3 \mathrm{~cm}^{3}\right)$ from both the core and tunnel were oven-dried $\left(105^{\circ} \mathrm{C}\right.$ for $\left.48 \mathrm{~h}\right)$, homogenized using a mortar and pestle, and analyzed for total $\mathrm{C}\left(\mathrm{C}_{\text {tot }}\right)$ and nitrogen $\left(\mathrm{N}_{\text {tot }}\right), \mathrm{C}_{\text {tot }}: \mathrm{N}_{\text {tot }}$ ratios, and isotope ratios $\delta^{15} \mathrm{~N}_{\text {tot }}$ using an elemental analyzer (Finnigan DeltaPlus XP, Thermo Scientific) coupled to a Costech ECS4010 Elemental Analyzer (Costech Scientific, Valencia, California, USA) at the University of Alaska Stable Isotope Facility, Fairbanks, Alaska, USA. A subsample of the homogenized oven-dried sediments was acidified using muriatic acid $(31.45 \% \mathrm{HCl})$, rinsed five times with deionized (DI) water, and used to measure total organic carbon $\left(\mathrm{C}_{\text {org }}\right)$ and $\delta^{13} \mathrm{C}_{\text {org }}$ on the same elemental analyzer. Measurement of an internal laboratory standard (peptone, $n=7$ ) indicated measurement precision of $\leq 0.4 \%$ for both sets of $\mathrm{C}$ and $\mathrm{N}$ isotopes. Sediment $\mathrm{C}_{\text {tot }}$, $\mathrm{C}_{\text {org }}$, and $\mathrm{N}_{\text {tot }}$ contents are reported in weight percentage (wt \%). $\delta^{13} \mathrm{C}_{\text {org }}$ and $\delta^{15} \mathrm{~N}_{\text {tot }}$ contents are reported in parts per mil (\%o). All $\delta^{13} \mathrm{C}_{\text {org }}$ and $\delta^{15} \mathrm{~N}_{\text {tot }}$ values are expressed relative to Vienna Pe Dee Belemnite (VPDB) and ambient air, respectively. We report all results in mean \pm standard deviation (SD).

\subsection{Anaerobic laboratory incubations}

Sediment slurries were prepared and incubated in triplicate for 21 depths along the Vault Lake core and 16 depths along the Vault Creek permafrost tunnel (Figs. 1 and 2; Table 2). We homogenized sediment samples under anaerobic conditions with $\mathrm{O}_{2}$-free, sterilized DI water while flushing the slurry with ultra-high-purity (UHP) $\mathrm{N}_{2}$ gas (Air Liquide,
Houston, Texas, USA) in a solution container. Subsamples of slurry were oven-dried $\left(105^{\circ} \mathrm{C}\right.$ for $\left.48 \mathrm{~h}\right)$ and analyzed for dry sediment $\mathrm{C}_{\text {tot }}, \mathrm{C}_{\text {org }}, \mathrm{N}_{\text {tot }}, \delta^{13} \mathrm{C}_{\text {org }}$, and $\delta^{15} \mathrm{~N}_{\text {tot }}$ contents using the methods outlined above. Fifty milliliters of the anaerobic slurry was transferred to $100 \mathrm{~mL}$ glass serum bottles (Wheaton, Millville, New Jersey, USA) using a pipette. Serum bottles were degassed using a constant stream of UHP $\mathrm{N}_{2}$ gas and sealed with butyl rubber stoppers (Bellco Glass, Vineland, New Jersey, USA). The slurry in each incubation bottle was reduced by injecting L-cysteine (Sigma-Aldrich, St. Louis, Missouri, USA) to a concentration of $0.025 \%$ ( $w t / v$; Gorini, 1961). Anaerobic conditions in the bottles were subsequently verified by measuring $\mathrm{O}_{2}$ concentrations in the headspace using gas chromatography (Shimadzu GC2014, Shimadzu, Kyoto, Japan). We incubated the bottles at $3{ }^{\circ} \mathrm{C}$ until linear $\mathrm{CH}_{4}$ production rates were achieved in all Vault Lake sediment core incubation bottles. The bottles remained sealed to maintain anaerobic conditions throughout the incubation period, which was 175 days for lake sediments and 220 days for permafrost tunnel samples.

We measured headspace $\mathrm{CH}_{4}$ concentrations in each incubation bottle every 30 days using gas chromatography (Shimadzu GC-2014, Shimadzu, Kyoto, Japan). $\mathrm{CH}_{4}$ production potential rates were calculated by the slope of the $\mathrm{CH}_{4}$ concentration in headspace over time. We normalized $\mathrm{CH}_{4}$ production rates across incubation bottles in two ways: dividing the $\mathrm{CH}_{4}$ production rates by the mass of dry sediment and the mass of $\mathrm{C}_{\text {org }}$ in each bottle. $\mathrm{CH}_{4}$ production rates are reported in units of $\mu \mathrm{g} C-\mathrm{CH}_{4} \mathrm{~g} \mathrm{dw}^{-1} \mathrm{~d}^{-1}$ and $\mu \mathrm{g} \mathrm{C}-\mathrm{CH}_{4} \mathrm{gC}_{\text {org }}^{-1} \mathrm{~d}^{-1}$. We calculated whole sedimentcolumn $\mathrm{CH}_{4}$ production $\left(\mu \mathrm{g} \mathrm{C}-\mathrm{CH}_{4} \mathrm{~cm}^{-2} \mathrm{~d}^{-1}\right.$ ) for the cen- 
Table 2. Vault Lake core and Vault Creek permafrost tunnel facies, their depths and thicknesses, and the representative number of samples used in anaerobic laboratory incubations.

\begin{tabular}{llrrc}
\hline Profile & Facies & $\begin{array}{r}\text { Depth } \\
(\mathrm{cm})\end{array}$ & $\begin{array}{r}\text { Thickness } \\
(\mathrm{cm})\end{array}$ & $\begin{array}{r}\text { Incubation } \\
\text { samples }(n)\end{array}$ \\
\hline Vault L. core & Organic-rich mud & $0-152$ & 152 & 6 \\
& Lacustrine silt & $153-330$ & 178 & 3 \\
& Taberite & $331-507$ & 177 & 6 \\
& Recently thawed taberite & $508-550$ & 43 & 4 \\
& Transitional permafrost & $551-590$ & 40 & 3 \\
Vault Cr. tunnel & Permafrost (silt) & $0-2400$ & 2400 & 7 \\
& Permafrost & $2400-4000$ & 1600 & 9 \\
& (Silty matrix of gravel) & & & \\
\hline
\end{tabular}

ter lake core as the sum of facies' products of mean $\mathrm{CH}_{4}$ production ( $\left.\mu \mathrm{g} \mathrm{C}-\mathrm{CH}_{4} \mathrm{~g} \mathrm{dw}^{-1} \mathrm{~d}^{-1}\right)$, dry bulk density $\left(\mathrm{g} \mathrm{cm}^{-3}\right)$, and facies thickness $(\mathrm{cm})$. Using a conversion factor of 0.01 , we report whole sediment-column $\mathrm{CH}_{4}$ production in units of $\mathrm{gC}-\mathrm{CH}_{4} \mathrm{~m}^{-2} \mathrm{~d}^{-1}$.

\subsection{Statistics}

Sediment characteristics (dry bulk density, gravimetric water content, $\mathrm{C}_{\text {tot }}, \mathrm{C}_{\text {org }}, \mathrm{N}_{\text {tot }}, \mathrm{C}_{\text {tot }}: \mathrm{N}_{\text {tot }}, \delta^{13} \mathrm{C}_{\text {org }}$, and $\delta^{15} \mathrm{~N}_{\text {tot }}$ ) and $\mathrm{CH}_{4}$ production rates $\left(\mu \mathrm{g} \mathrm{C}-\mathrm{CH}_{4} \mathrm{gdw}^{-1} \mathrm{~d}^{-1}, \mu \mathrm{g} \mathrm{C}-\mathrm{CH}_{4}\right.$ $\mathrm{gC}_{\text {org }}^{-1} \mathrm{~d}^{-1}$ ) were tested for normal distribution using the Jarque-Bera test (MATLAB R2013a Student Version, MathWorks, Natick, Massachusetts, USA). All parameters except $\mathrm{CH}_{4}$ production rate expressed as $\mu \mathrm{g} \mathrm{C}-\mathrm{CH}_{4} \mathrm{~g} \mathrm{C}_{\text {org }}^{-1} \mathrm{~d}^{-1}$ were non-normally distributed $(\alpha=0.05)$; therefore, differences among facies were tested for statistical significance using Wilcoxon rank sum tests (MATLAB R2013a Student Version). Differences were considered statistically significant when $p \leq 0.05$. Spearman's rank correlation coefficients (MATLAB R2013a Student Version) were used to determine correlations between explanatory variables $\left(\mathrm{C}_{\mathrm{tot}}\right.$, $\mathrm{C}_{\text {org }}, \mathrm{N}_{\text {tot }}$, and $\mathrm{C}_{\text {tot }}: \mathrm{N}_{\text {tot }}$ ratios) and anaerobic $\mathrm{CH}_{4}$ production $\left(\mu \mathrm{g} \mathrm{C}-\mathrm{CH}_{4} \mathrm{~g} \mathrm{dw}^{-1} \mathrm{~d}^{-1}\right)$ in our incubations.

\section{Results}

\subsection{Lake age, morphology, and talik temperatures}

Calibrated ages of macrofossils picked from the Organic-rich mud facies of the Vault Lake core ranged from $190 \pm 20$ to $405 \pm 25$ calendar years BP (Fig. 2; Table 1).

Lake water depths determined at the borehole locations ranged from 0.7 to $4.6 \mathrm{~m}$ (mean $\pm \mathrm{SD} 2.9 \pm 1.1 \mathrm{~m}, n=14$ boreholes). Talik depths below the sediment-water interface ranged from 0 to $8.8 \mathrm{~m}$ (mean $\pm \mathrm{SD} 5.9 \pm 2.1 \mathrm{~m}, n=14$ boreholes). Figure 1c shows borehole data for the long axis of the lake, including the lake center borehole (BH 14) from which our sediment core was taken. The talik was $\sim 50 \%$ thicker adjacent to the southern thermokarst margin than it was in the lake center.

Vertical profile temperatures measured along the borehole in the center of Vault Lake, where water depth was $4.0 \mathrm{~m}$ and talik thickness was $5.7 \mathrm{~m}$, ranged from -0.40 to $4.22^{\circ} \mathrm{C}$ (Fig. 3a). In the borehole adjacent to the southwest thermokarst margin ( $6.1 \mathrm{~m}$ offshore), talik thickness was greater $(8.6 \mathrm{~m})$, lake water shallower $(1.4 \mathrm{~m})$, and sediment temperatures were warmer than in the lake center $\left(-0.40\right.$ to $14.00^{\circ} \mathrm{C}$; Fig. $\left.3 b\right)$. In both profiles, temperatures in the shallower sediment depths $(-0.5$ to $-1.0 \mathrm{~m}$ $(0 \mathrm{~m}=$ sediment/water interface $)$, temperature range 0.14 to $14.00^{\circ} \mathrm{C}$, mean annual temperature $3.57^{\circ} \mathrm{C}$ ) were warmer and showed clear seasonal variations (Fig. 3a and b). Temperatures along the thaw boundary $(-5.70$ to $-8.85 \mathrm{~m}$, temperature range -0.40 to $2.07^{\circ} \mathrm{C}$, mean annual temperature $0.13^{\circ} \mathrm{C}$ ) were colder and relatively more consistent throughout the year.

The temperature data also indicated a strong thermal lag and lateral offset in the propagation of summer heat into deeper sediments and the lake center. The maximum temperature in the near-shore surface sediments $\left(14.00^{\circ} \mathrm{C}\right.$ at $-0.5 \mathrm{~m}$ ) occurred on 10 August 2013, while maximum temperature at $-6.2 \mathrm{~m}\left(2.07^{\circ} \mathrm{C}\right)$ and $-8.9 \mathrm{~m}\left(-0.03^{\circ} \mathrm{C}\right)$ depths in the same vertical profile occurred on 22 October 2013. In the lake center, where water depth was deeper, the maximum temperature of $4.22{ }^{\circ} \mathrm{C}$ occurred on 24 September 2013 at $-0.5 \mathrm{~m}$ sediment depth, and also showed a thermal lag of heat propagation to greater depths in the same profile.

\subsection{Sediment attributes}

Sediment properties in the Vault Lake core and Vault Creek permafrost tunnel varied by facies and are summarized in Table 3. Magnetic susceptibility (MS) results indicate two points with low MS values at approximately 100 and $400 \mathrm{~cm}$ depth in the lake core (Fig. 4). These points are associated with diamagnetic materials in the core, potentially indicative of tephra. Tephra layers were observed in the Vault Creek permafrost tunnel, albeit at greater depths below the surface 

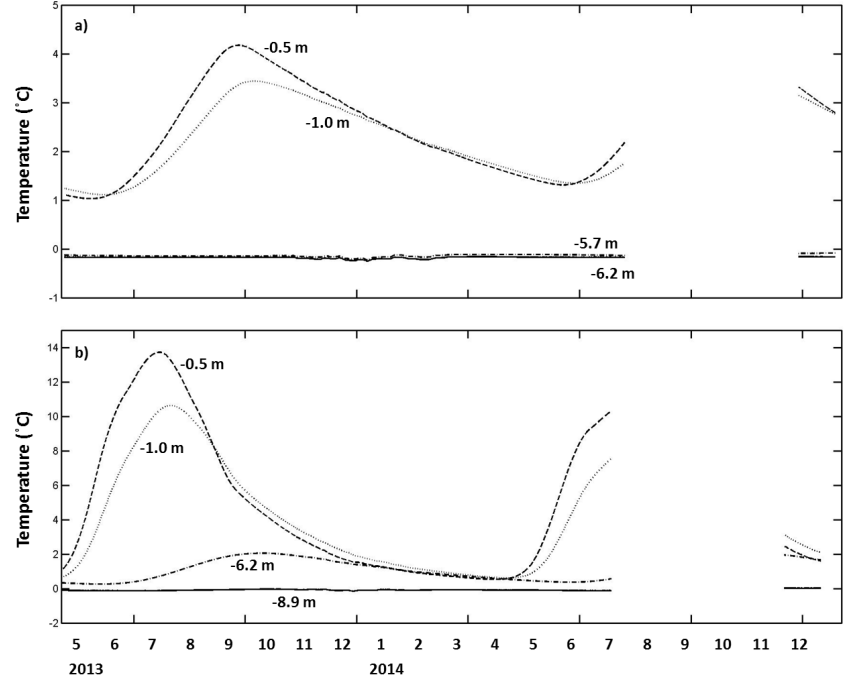

Figure 3. Vertical profile temperatures measured in the lake center $(<1 \mathrm{~m}$ from BH14; a) and $6.1 \mathrm{~m}$ offshore of the southwestern thermokarst margin (b). Negative depth values indicate depth from the sediment-water interface $(0 \mathrm{~m})$ at each of the examined boreholes. Loggers did not record temperature between 25 July and 11 November 2014

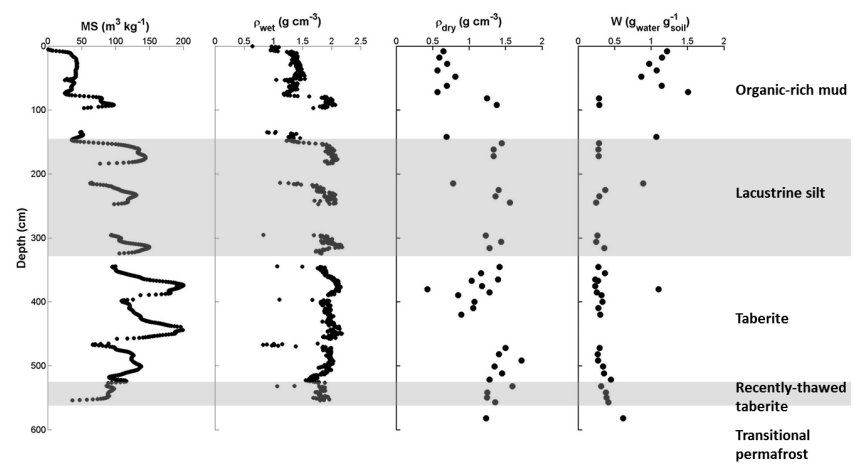

Figure 4. Depth profiles for magnetic susceptibility (MS), wet bulk density $\left(\rho_{\text {wet }}\right)$, dry bulk density $\left(\rho_{\text {dry }}\right)$, and gravimetric water content (W) in the Vault Lake sediment core. Two MS values at 95.4 and $405.4 \mathrm{~cm}$ were -493.1 and $-488.0 \mathrm{~m}^{3} \mathrm{~kg}^{-1}$, respectively (not shown).

(Meyer et al., 2008). The Organic-rich mud facies had the lowest bulk density values in the lake core (Table 3). Differences in dry bulk density values between the remaining facies and between the silt and silty matrix of the gravel horizons of the permafrost tunnel were not statistically significant. Organic-rich mud had higher gravimetric water content values and Taberite had lower values than the remainder of the core (Table 3). High dry bulk density values had a strong linear correlation with low gravimetric water contents in samples $\left(R^{2}=0.74\right)$.

Sediment geochemical parameters varied among the lake core and permafrost tunnel facies (Fig. 5) and are sum-

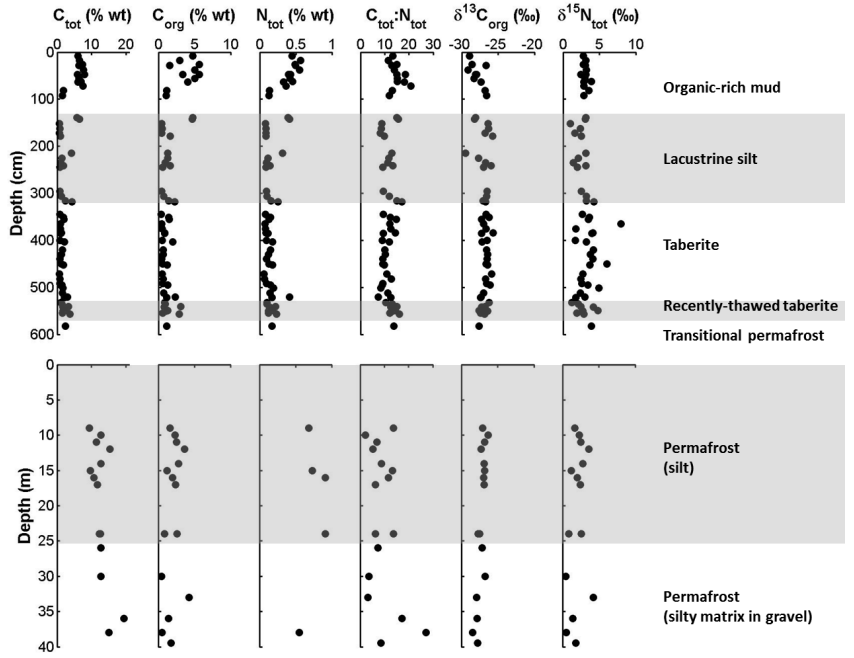

Figure 5. Depth profiles for sediment geochemical characteristics: total carbon $\left(\mathrm{C}_{\text {tot }}\right)$, organic carbon $\left(\mathrm{C}_{\text {org }}\right)$, total $\mathrm{N}\left(\mathrm{N}_{\text {tot }}\right), \mathrm{C}_{\text {tot }}: \mathrm{N}_{\text {tot }}$

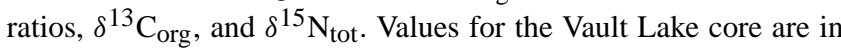
the top panel; values for the Vault Creek permafrost tunnel are in the bottom panel.

marized in Table 4. The Organic-rich mud facies had the highest soil $\mathrm{C}$ concentrations (mean $\pm \mathrm{SD} \mathrm{C}_{\text {tot }} 6.01 \pm 1.90$; $\mathrm{C}_{\text {org }} 3.83 \pm 1.66$ ) in the core (Table 4), while the Taberite facies had the lowest $\mathrm{C}$ concentrations (mean $\pm \mathrm{SDC}_{\text {tot }} 1.21 \pm$ $\left.0.44 ; \mathrm{C}_{\text {org }} 0.84 \pm 0.45\right)$. The remaining lake core facies grouped together had lower $\mathrm{C}$ concentrations $\left(\mathrm{C}_{\text {tot }} 1.24\right.$ $\left.2.52 \% ; \mathrm{C}_{\text {org }} 0.84-1.52 \%\right)$. Table 4 shows the $\mathrm{C}$ concentrations for individual facies, but $\mathrm{C}$ concentrations among the Lacustrine silt, Recently thawed taberite, and Transitional permafrost were not significantly different from each other.

High levels of $\mathrm{C}_{\text {tot }}$ were observed in the permafrost tunnel (Table 4), and differences between relatively high levels of $\mathrm{C}_{\text {tot }}$ (mean $14.5 \% \mathrm{wt}$ ) and lower levels of $\mathrm{C}_{\text {org }}$ (mean $1.9 \% \mathrm{wt}$ ) indicate significant inorganic $\mathrm{C}$ content in the permafrost tunnel soils (mean \pm SD $86.5 \pm 8.4 \%$ of total C). In contrast, inorganic $\mathrm{C}$ was $33.4 \pm 17.8 \%$ of total $\mathrm{C}$ in the lake sediment core samples.

Among the lake core facies, the highest $\mathrm{N}_{\text {tot }}$ concentrations occurred in the Organic-rich mud $(0.40 \pm 0.13 \% \mathrm{wt})$. The permafrost tunnel horizons also had high $\mathrm{N}_{\text {tot }}$ concentrations $(2.39 \pm 2.37 \% \mathrm{wt})$. The Taberite facies had the lowest $\mathrm{C}_{\text {tot }}: \mathrm{N}_{\text {tot }}$ ratios among all facies and the Organic-rich mud had the highest $\mathrm{C}_{\text {tot }}$ : $\mathrm{N}_{\text {tot }}$ ratios, but there were no statistically significant differences among the other core facies. The Taberite facies had higher $\delta^{13} \mathrm{C}_{\text {org }}$ values $(-26.58 \pm 0.44)$ than the remaining lake sediment core facies (Table 4).

\section{3 $\mathrm{CH}_{4}$ production potentials and depth-integrated $\mathrm{CH}_{4}$ production}

Mean $\mathrm{CH}_{4}$ production potentials varied across the lake core facies (Table 5) and no $\mathrm{CH}_{4}$ production was observed in 
Table 3. Summary of dry bulk density $(\rho)$ and gravimetric water content (W) data from the Vault Lake core and the Vault Creek permafrost tunnel. Data are presented as mean \pm SD.

\begin{tabular}{llcc}
\hline \multirow{2}{*}{ Profile } & \multicolumn{2}{c}{ Sample } & \multicolumn{2}{c}{ Sediment properties } \\
& Facies & $\rho\left(\mathrm{g} \mathrm{cm}^{-3}\right)$ & $\mathrm{W}\left(\mathrm{g}_{\text {water }} \mathrm{g}_{\text {sediment }}\right)$ \\
\hline \multirow{2}{*}{ Vault L. core } & Organic-rich mud & $0.79 \pm 0.29^{\mathrm{a}}$ & $0.96 \pm 0.39^{\mathrm{a}}$ \\
& Lacustrine silt & $1.32 \pm 0.21$ & $0.35 \pm 0.19$ \\
& Taberite & $1.22 \pm 0.33$ & $0.29 \pm 0.04^{\mathrm{b}}$ \\
& Recently thawed taberite & $1.36 \pm 0.15$ & $0.38 \pm 0.05$ \\
\multirow{2}{*}{ Vault Cr. tunnel } & $1.29 \pm 0.06$ & $0.52 \pm 0.10$ \\
& Transitional permafrost & $0.89 \pm 0.28$ & $0.91 \pm 0.40$ \\
& Permafrost (silt) & $1.28 \pm 0.21$ & $0.44 \pm 0.20$ \\
\hline
\end{tabular}

a, b Different letters indicate significant differences from other facies in the same profile at the $\alpha=0.05$ level. Vault $\mathrm{L}$. core and Vault Cr. tunnel profiles were analyzed separately.

Table 4. Summary of geochemical properties and stable isotopes measured on sediment samples from the Vault Lake core and Vault Creek permafrost tunnel. Data are presented as mean \pm SD.

\begin{tabular}{|c|c|c|c|c|c|c|c|}
\hline \multirow{2}{*}{\multicolumn{2}{|c|}{$\begin{array}{r}\text { Sample } \\
\text { Facies }\end{array}$}} & \multicolumn{6}{|c|}{ Geochemistry } \\
\hline & & $\mathrm{C}_{\text {tot }}(\% \mathrm{wt})$ & $\mathrm{C}_{\text {org }}(\% \mathrm{wt})$ & $\mathrm{N}_{\text {tot }}(\% \mathrm{wt})$ & $\mathrm{C}_{\text {tot }}: \mathrm{N}_{\text {tot }}$ & $\delta^{13} \mathrm{C}_{\text {org }}(\% \circ)$ & $\delta^{15} \mathrm{~N}_{\text {tot }}(\% o)$ \\
\hline \multirow[t]{5}{*}{ Vault L. core } & Organic-rich mud & $6.01 \pm 1.90^{\mathrm{a}}$ & $3.83 \pm 1.66^{\mathrm{a}}$ & $0.40 \pm 0.13^{\mathrm{a}}$ & $15.0 \pm 2.5^{\mathrm{a}}$ & $-28.11 \pm 1.12$ & $3.05 \pm 0.34^{\mathrm{a}}$ \\
\hline & Lacustrine silt & $1.60 \pm 1.24$ & $1.04 \pm 0.58$ & $0.13 \pm 0.07$ & $11.3 \pm 2.7$ & $-26.85 \pm 0.92$ & $2.49 \pm 0.90$ \\
\hline & Taberite & $1.24 \pm 0.44^{\mathrm{b}}$ & $0.84 \pm 0.45^{\mathrm{b}}$ & $0.12 \pm 0.04^{\mathrm{b}}$ & $10.8 \pm 1.9^{\mathrm{b}}$ & $-26.58 \pm 0.44^{\mathrm{a}}$ & $3.70 \pm 1.46^{\mathrm{a}}$ \\
\hline & Recently thawed taberite & $2.04 \pm 0.79$ & $1.36 \pm 0.80$ & $0.18 \pm 0.10$ & $12.2 \pm 2.4$ & $-26.94 \pm 0.51$ & $2.72 \pm 1.13$ \\
\hline & Transitional permafrost & $2.52 \pm 1.10$ & $1.52 \pm 1.18$ & $0.18 \pm 0.05$ & $14.0 \pm 1.9$ & $-27.28 \pm 0.39$ & $2.88 \pm 0.98$ \\
\hline \multirow[t]{2}{*}{ Vault Cr. tunnel } & Permafrost (silt) & $11.88 \pm 1.75^{\mathrm{b}}$ & $2.21 \pm 0.80^{\mathrm{a}}$ & $1.91 \pm 1.60$ & $8.8 \pm 4.1$ & $-27.02 \pm 0.40$ & $2.21 \pm 0.80^{\mathrm{a}}$ \\
\hline & $\begin{array}{l}\text { Permafrost } \\
\text { (Silty matrix of gravel) }\end{array}$ & $18.77 \pm 6.80^{\mathrm{a}}$ & $1.31 \pm 1.66^{\mathrm{b}}$ & $3.19 \pm 3.32$ & $11.2 \pm 9.4$ & $-27.63 \pm 0.60$ & $1.40 \pm 1.55^{b}$ \\
\hline
\end{tabular}

a, b Different letters indicate significant differences from other facies in the same profile at the $\alpha=0.05$ level. Vault L. core and Vault Cr. tunnel profiles were analyzed separately.

the thawed permafrost tunnel samples. $\mathrm{CH}_{4}$ production potentials in the lake core over the 175-day incubation period ranged from 0.002 to $8.08 \mu \mathrm{g} \mathrm{C}-\mathrm{CH}_{4} \mathrm{~g} \mathrm{dw}^{-1} \mathrm{~d}^{-1}$ and 0.51 to $178.9 \mu \mathrm{g} \mathrm{C}-\mathrm{CH}_{4} \mathrm{gC}_{\text {org }}^{-1} \mathrm{~d}^{-1}$ (Fig. 6). The highest production potentials were observed in the Organic-rich mud and the lowest rates occurred in Taberites and Transitional permafrost (Table 5). We found that $\mathrm{C}_{\text {tot }}(r=0.47, p=0.043)$ and $\mathrm{C}_{\text {org }}(r=0.47, p=0.043)$ were positively correlated with $\mathrm{C}-\mathrm{CH}_{4}$ production. Total $\mathrm{N}$ and $\mathrm{C}_{\text {tot }}: \mathrm{N}_{\text {tot }}$ ratios were unrelated to $\mathrm{CH}_{4}$ production potentials in our incubations.

The ratios $(R)$ of facies' $\mathrm{CH}_{4}$ production potentials to their thickness in the lake center sediment column revealed the highest $\mathrm{CH}_{4}$ production per unit of sediment were in the Organic-rich mud $(R=2.6)$ and Recently thawed taberite ( $R=1.2$ ) facies, while $R$ of the remaining facies was lower ( $R=0.2$ to 0.5 ; Table 5). Specifically, the Organic-rich mud facies, which represented $26 \%$ of the sediment column thickness, dominated $(67 \%)$ whole-column $\mathrm{CH}_{4}$ production in the lake center sediment core (5.2 $\mathrm{g} \mathrm{C}_{-} \mathrm{CH}_{4} \mathrm{~m}^{-2} \mathrm{~d}^{-1}$; Table 5). The Lacustrine silt facies, which represented $30 \%$ of the sediment column thickness, had the second largest contribution

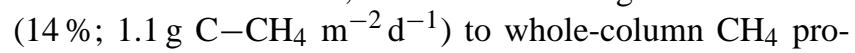
duction. Results for other facies are shown in Table 5.

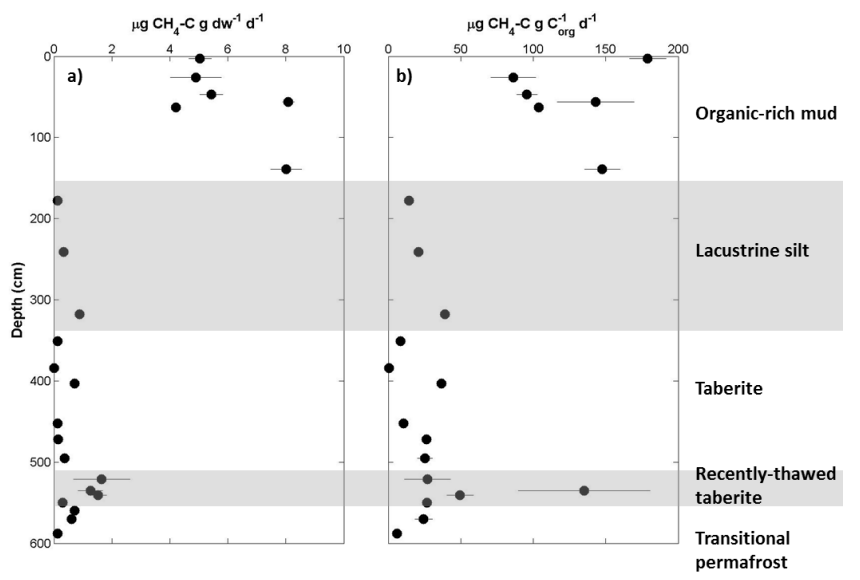

Figure 6. Depth profile for $\mathrm{CH}_{4}$ production potentials in the Vault Lake core. Samples were anaerobically incubated at $3{ }^{\circ} \mathrm{C}$. Methane production potentials are represented as mean value \pm SD among replicates and normalized per gram dry weight sediment (a) and per gram organic carbon $\left(\mathrm{C}_{\mathrm{org}} ; \mathbf{b}\right)$. 
Table 5. Summary of facies' $\mathrm{CH}_{4}$ production potentials and depth-integrated $\mathrm{CH}_{4}$ production for the total sediment column. Data are presented as mean $\pm \mathrm{SD}$. It should be noted that, based on optical properties (Fig. 2), dry bulk density (mean $\pm \mathrm{SD}, 1.31 \pm 0.07 \mathrm{~g} \mathrm{~cm}^{-3}$ ), gravimetric moisture content $(29 \pm 0.00 \%)$, and $\mathrm{C}_{\text {org }}(1.64 \%)$ values measured on two samples in the depth interval $77-97 \mathrm{~cm}$ of the core, which were similar to those of Lacustrine Silt and very different from the remainder of the Organic-rich mud facies segments, we applied $\mathrm{CH}_{4}$ production rates measured on Lacustrine silt samples to this $21 \mathrm{~cm}$ interval of the Organic-rich mud section. This was done because no samples from this $21 \mathrm{~cm}$ thick, mineral-dominated segment of organic-rich mud were represented in the incubation.

\begin{tabular}{|c|c|c|c|c|c|c|c|}
\hline \multirow[b]{2}{*}{ Profile } & \multirow{2}{*}{$\begin{array}{l}\text { Sample } \\
\text { Facies }\end{array}$} & \multicolumn{2}{|c|}{$\begin{array}{c}\mathrm{CH}_{4} \text { production potentials } \\
\left(\mu \mathrm{gC}-\mathrm{CH}_{4} \mathrm{~d}^{-1}\right)\end{array}$} & \multicolumn{4}{|c|}{ Sediment column $\mathrm{CH}_{4}$ production } \\
\hline & & $\mathrm{g} \mathrm{dw}^{-1}$ & $\mathrm{~g} \mathrm{C}_{\text {org }}^{-1}$ & $\begin{array}{l}\mathrm{gC}-\mathrm{CH}_{4} \\
\mathrm{~m}^{-2} \mathrm{~d}^{-1}\end{array}$ & $\begin{array}{l}\% \text { Total } \\
\mathrm{C}-\mathrm{CH}_{4} \\
\text { production }\end{array}$ & $\begin{array}{l}\% \text { Total } \\
\text { column } \\
\text { thickness }\end{array}$ & $\begin{array}{l}R \\
\text { (\% production/ } \\
\% \text { thickness) }\end{array}$ \\
\hline \multirow{5}{*}{ Vault L. core } & Organic-rich mud & $5.95 \pm 1.67^{\mathrm{a}}$ & $125.9 \pm 36.2^{\mathrm{a}}$ & 5.2 & 67 & 26 & 2.6 \\
\hline & Lacustrine silt & $0.45 \pm 0.39$ & $24.6 \pm 12.8$ & 1.1 & 14 & 30 & 0.5 \\
\hline & Taberite & $0.25 \pm 0.26^{\mathrm{b}}$ & $17.9 \pm 13.6$ & 0.5 & 7 & 30 & 0.2 \\
\hline & Recently thawed taberite & $1.18 \pm 0.61$ & $59.6 \pm 51.5$ & 0.7 & 9 & 7 & 1.2 \\
\hline & Transitional permafrost & $0.48 \pm 0.31$ & $15.3 \pm 9.1^{b}$ & 0.2 & 3 & 7 & 0.5 \\
\hline
\end{tabular}

a, b Different letters indicate significant differences from other facies in the same profile at the $\alpha=0.05$ level.

\section{Discussion}

\section{1 $\mathrm{CH}_{4}$ production potentials}

Our study indicates that, in the center of the lake, the Organic-rich mud facies contributed the most $(67 \%)$ to whole-column $\mathrm{CH}_{4}$ production despite occupying a lesser fraction $(26 \%)$ of sediment column thickness. This is consistent with findings from a study examining an $8 \mathrm{~m}$ deep Holocene permafrost core from the Lena Delta, in which the top $(125 \mathrm{~cm})$ section of permafrost sediments were also found to have the highest observed $\mathrm{CH}_{4}$ production in the sediment column (Wagner et al., 2007).

A main reason for the Organic-rich mud facies in our study having high $\mathrm{CH}_{4}$ production potentials is its relatively high $\mathrm{OM}$ content. Past studies have suggested that $\mathrm{CH}_{4}$ production rates in natural ecosystems are controlled by environmental conditions, including substrate availability (Tranvik et al., 2009; Wallmann et al., 2006; Bergman et al., 1999; Valentine et al., 1994; Westermann, 1993). Correlation analyses showed that $\mathrm{CH}_{4}$ production in our study was positively correlated to sediment $\mathrm{C}_{\text {tot }}$ and $\mathrm{C}_{\text {org }}$ contents ( $p=0.043$ for both). This indicates that facies with higher $\mathrm{C}$ contents, such as the Organic-rich mud, would have higher $\mathrm{CH}_{4}$ production potentials compared to other facies.

Following the Organic-rich mud facies, relatively high $\mathrm{CH}_{4}$ production potentials were also observed in the Recently thawed taberite facies. However, the narrowness of the Recently thawed taberite in the center of the lake limited its overall contribution to total sediment column $\mathrm{CH}_{4}$ production potentials. The thickest sequence, which consisted of combined Lacustrine silt and Taberite facies (60\% of total core thickness), had low $\mathrm{CH}_{4}$ production potentials, contributing only $21 \%$ of whole sediment column $\mathrm{CH}_{4}$ produc- tion potential. Our results of higher $\mathrm{CH}_{4}$ production in the Recently thawed taberite facies compared to the Lacustrine silt and Taberite facies are consistent with model simulations of $\mathrm{CH}_{4}$ production in a thermokarst lake that showed $\mathrm{CH}_{4}$ production among the thawed yedoma horizons to be highest along the talik's downward progressing thaw boundary (Kessler et al., 2012). Assuming homogenous C contents along the full yedoma profile in numerical modeling, the higher $\mathrm{CH}_{4}$ production at the thaw boundary was explained by fresh OM made available to microbial decomposition by permafrost thaw. Conversely, lower $\mathrm{CH}_{4}$ production in the overlying mineral-dominated sediments, which represent permafrost that thawed earlier, is explained by earlier microbial decomposition that previously exhausted a large fraction of the labile $\mathrm{C}$ pool of permafrost sediment $\mathrm{OM}$.

Total soil OC consists of various OC pools with turnover times ranging from less than a year to up to thousands of years (Schädel et al., 2014). OC pool sizes and turnover times significantly impact how OC behaves in the global $\mathrm{C}$ cycle and remain a significant uncertainty in estimating how permafrost OC will be processed as it thaws (Schädel et al., 2014; Strauss et al., 2013). In our study, $\mathrm{CH}_{4}$ production potential rates in the Recently thawed taberite facies, which we estimate thawed during approximately the previous decade based on downward talik growth rates determined through numerical modeling of a similar yedoma thermokarst lake system (Kessler et al., 2012), were approximately 4.7 times higher than those in the overlying taberite, which we estimate thawed over longer periods of time (up to 400 years). This suggests that, upon thaw, labile fractions of OC in the talik are depleted over decadal to century timescales and the remaining OC pool is less susceptible to processing upon thaw. Prior studies of Siberian yedoma suggest that approximately $30 \%$ of the yedoma $\mathrm{C}$ pool is bioavailable upon thaw under 
anaerobic conditions in yedoma-lake taliks (Walter Anthony et al., 2014). Under aerobic conditions, 5-30\% of the total $\mathrm{C}$ pool in both organic and mineral circumpolar permafrost samples are estimated to have a rapid turnover time (mean $0.35 \pm 0.6$ years) upon thaw (Schädel et al., 2014; Shaver et al., 2006). Remaining permafrost C contains $10-90 \%$ "slow" $\mathrm{C}$ (mean turnover time $7.21 \pm 4.32$ years) and $5-85 \%$ "passive" C (mean turnover time $>2500$ years; Schädel et al., 2014) under aerobic decomposition regimes. However, further research is necessary to determine the relative sizes of permafrost $\mathrm{C}$ pools and better assess what proportion of permafrost $\mathrm{OC}$ can be processed into $\mathrm{CH}_{4}$ upon thaw in an anaerobic thermokarst lake environment.

Within the Organic-rich mud facies, we observed higher $\mathrm{CH}_{4}$ production potentials $\left(\mathrm{g} \mathrm{C}_{\mathrm{org}}^{-1}\right.$ ) near the surface of the Vault Lake core and slightly decreasing $\mathrm{CH}_{4}$ production potentials with depth through the facies. Surface lake sediments originate from both allochthonous (terrestrial soils and vegetation) and autochthonous (i.e., lake biota) sources (Tranvik et al., 2009; Cole et al., 2007; Wetzel, 2001). Surface sediments typically contain the most recently deposited materials while deeper sediments represent older deposited materials (Smol, 2008; Cohen, 2003). The higher $\mathrm{CH}_{4}$ production near the surface of the Organic-rich mud facies may be explained by these more recently deposited surface sediments containing fresher, more labile substrates than the older, underlying sediments. Another possibility is that autochthonous organic matter in the surface sediments provides a labile $\mathrm{C}$ substrate that may prime decomposition of more recalcitrant allochthonous $\mathrm{C}$ in the sediments, leading to higher total $\mathrm{CH}_{4}$ production than in underlying sediments that do not receive the autochthonous $\mathrm{C}$.

\section{2 $\mathrm{CH}_{4}$ production potentials versus observed emissions}

Laboratory incubations measure maximum $\mathrm{CH}_{4}$ production potentials, while $\mathrm{CH}_{4}$ emissions observed in the field represent in situ production minus $\mathrm{CH}_{4}$ consumption, dissolved $\mathrm{CH}_{4}$, and trapped $\mathrm{CH}_{4}$ accumulating in the system (Blazewicz et al., 2012; Wright et al., 2011; Westermann, 1993). Because of this, the $\mathrm{CH}_{4}$ production potentials measured in our study may be higher than in situ $\mathrm{CH}_{4}$ production in the Vault thermokarst lake system, possibly explaining the discrepancies among potential $\mathrm{CH}_{4}$ production rates for the total lake center sediment core in our study $\left(2819 \mathrm{~g} \mathrm{CH}_{4}\right.$ $\mathrm{m}^{-2} \mathrm{yr}^{-1}$ ) and observed, lower $\mathrm{CH}_{4}$ emission rates from across Vault Lake (41 $\mathrm{g} \mathrm{CH}_{4} \mathrm{~m}^{-2} \mathrm{yr}^{-1}$; Sepulveda-Jauregui et al., 2015) and observations in the literature for northern $\left(>54^{\circ} \mathrm{N}\right)$ lakes $\left(\sim 7 \mathrm{~g} \mathrm{CH}_{4} \mathrm{~m}^{-2} \mathrm{yr}^{-1}\right.$; Bastviken et al., 2011). It is possible that $\mathrm{CH}_{4}$ emissions at Vault Lake are underestimated due to lake sediments storing large quantities of $\mathrm{CH}_{4}$ which are released during rare extreme-low pressure events and are unlikely to be captured by the ebullition ice-bubble surveys combined with bubble trap measurements utilized by Sepulveda-Jauregui et al. (2015). Other possible explanations for higher potential $\mathrm{CH}_{4}$ production rates observed by laboratory incubations in this study compared to emissions observed through field measurements are poor representation of spatial heterogeneity in the lake by a single lake center core and $\mathrm{CH}_{4}$ oxidation. Aerobic and anaerobic oxidation in sediments and the water column consumes a significant fraction of $\mathrm{CH}_{4}$ produced in lakes (Lofton et al., 2014; Borrel et al., 2011; Deutzmann and Schink, 2011; Bastviken et al., 2008; Kankaala et al., 2006). A simulated $\mathrm{CH}_{4}$ production study found $\mathrm{CH}_{4}$ production in a modeled thermokarst lake talik was up to 10 times higher than observed emissions in the field (Kessler et al., 2012). Produced $\mathrm{CH}_{4}$ may also be oxidized in anaerobic environments (Gupta et al., 2013; Smemo and Yavitt, 2007; Valentine, 2002), but the magnitude of anaerobic $\mathrm{CH}_{4}$ oxidation in lake environments is not well understood. The combined effects of aerobic and anaerobic $\mathrm{CH}_{4}$ oxidation may also account for, in part, the higher talik $\mathrm{CH}_{4}$ production potentials compared to lake emissions observed by Kessler et al. (2012).

Differences between our incubation temperature $\left(3{ }^{\circ} \mathrm{C}\right)$ and actual temperatures in the talik environment may also lead to some differences between the $\mathrm{CH}_{4}$ production potentials observed in our incubations and in situ $\mathrm{CH}_{4}$ production at Vault Lake. Observed annual temperatures under Vault Lake ranged from -0.4 to $14.0^{\circ} \mathrm{C}$ (mean $\pm \mathrm{SD} 1.61 \pm$ $2.80^{\circ} \mathrm{C}$ ). Microorganisms show increased methanogenesis with temperature increases (Yvon-Durocher et al., 2014; Yavitt et al., 2005; Schulz et al., 1997). Therefore, depending on the actual temperatures throughout the talik profile, $\mathrm{CH}_{4}$ production rates at a given time at Vault Lake may be higher or lower than those measured at our reference incubation temperature of $3^{\circ} \mathrm{C}$.

\subsection{Spatial patterns of $\mathrm{CH}_{4}$ production and emission within lakes}

Previous field and modeling studies found $\mathrm{CH}_{4}$ emissions to be up to an order of magnitude higher along thermokarst margins of yedoma lakes than in lake centers (Kessler et al., 2012; Walter et al., 2006). While our sediment incubation study was limited to a single lake center core, other physical data measured along the thermokarst margin at Vault Lake lend support to the findings of previous studies. The talik was $50 \%$ deeper along the expanding thermokarst lake margin (measured $6.1 \mathrm{~m}$ offshore; Sect. 3.1) compared to the lake center core site. This suggests that the Recently thawed taberite facies would be substantially thicker along the lake margin than in the lake center, though individual facies thicknesses were not measured. This would also be consistent with field measurements of ${ }^{14} \mathrm{C}-\mathrm{CH}_{4}$ ages being older (35 000 to 43000 years old) along yedoma thermokarst lake margins compared to lake centers (Brosius et al., 2012; Kessler et al., 2012; Walter et al., 2006). Based on field observations of cross-basin sediment stratigraphy in other yedoma lakes 
(Walter Anthony et al., 2014; Farquharson et al., 2015), it is possible that the overlying lake sediment (Organic-rich mud facies) is thinner along the lake margin than in our lake center core; however, Walter Anthony et al. (2014) observed $>2 \mathrm{~m}$ thick lake sediments within $15 \mathrm{~m}$ of the shore in much larger Siberian yedoma thermokarst lakes. Regardless of relative facies thicknesses, the thermokarst margin zone of the lake was more recently converted from permafrost-dominated terrestrial landscape into an open-water lake environment compared to the lake center core location. This suggests that sediments along the margin have had less time to decompose and, therefore, should have an overall higher fraction of labile OM remaining, consistent with higher total-column $\mathrm{CH}_{4}$ production rates described in the literature.

\section{4 $\mathrm{CH}_{4}$ production in thermokarst, permafrost, and non-permafrost systems}

Among long-term anaerobic incubations (> 115 days), observed $\mathrm{CH}_{4}$ production rates in the Vault Lake sediment core incubations at $3{ }^{\circ} \mathrm{C}$ were comparable to rates observed in incubations of shallow $(<1 \mathrm{~m})$ permafrost from non-lake environments in Alaska (0.01 to $1.14 \mu \mathrm{g} \mathrm{C}-\mathrm{CH}_{4} \mathrm{~g} \mathrm{dw}^{-1} \mathrm{~d}^{-1}$; Lee et al., 2012). However, these soil samples were incubated at a significantly higher temperature $\left(15^{\circ} \mathrm{C}\right)$, which would yield higher $\mathrm{CH}_{4}$ production rates than incubations performed at $3{ }^{\circ} \mathrm{C}$. Terrestrial soils from other shallow $(<1 \mathrm{~m})$ permafrost and active layer sites in Alaska incubated at $5{ }^{\circ} \mathrm{C}$ (Waldrop et al., 2010) produced $\mathrm{CH}_{4}$ at rates approximately an order of magnitude lower than the Vault Lake sediments in our study. Some of the sampling locations of Lee et al. (2012) and Waldrop et al. (2010) are underlain by yedoma-type permafrost; however, samples collected from shallow surface depths $(\leq 1 \mathrm{~m})$ were likely disturbed and thawed at some point during the Holocene, as indicated by the depth of Pleistocene ice-wedge surfaces (Jorgenson et al., 2013; Kanevskiy et al., 2011; Meyer et al., 2008). Deeper Pleistocene-aged yedoma soils (up to $5 \mathrm{~m}$ depth) from the Lena Delta region of Siberia incubated at $4{ }^{\circ} \mathrm{C}$ had similar $\mathrm{CH}_{4}$ production rates (approximately 0.1 to $1.3 \mu \mathrm{g} \mathrm{C}-\mathrm{CH}_{4} \mathrm{~g} \mathrm{dw}^{-1} \mathrm{~d}^{-1}$; Knoblauch et al., 2013) to the lake sediment facies dominated by thawed yedoma in our study; however, these high rates in the nonlake yedoma sediments in Siberia were only observed after a significant lag time (average 963 days). Comparisons across these studies suggest that undisturbed Pleistoceneaged yedoma permafrost may have more biolabile OM than younger or previously thawed yedoma permafrost soils. This conclusion is consistent with findings of Lee et al. (2012), in which yedoma samples had the highest anaerobic $\mathrm{C}$ release per gram soil $\mathrm{C}$ among a variety of mineral soil samples.

$\mathrm{CH}_{4}$ production rates in high latitude, non-permafrost lake sediments (eight lakes in central Sweden) incubated at $4{ }^{\circ} \mathrm{C}$ were generally much lower $\left(0.002\right.$ to $0.06 \mu \mathrm{g} \mathrm{C}-\mathrm{CH}_{4}$ $\mathrm{gdw}^{-1} \mathrm{~d}^{-1}$; Duc et al., 2010) than the rates we observed in the Organic-rich mud facies of the Vault Lake sediment core.
These differences could be due to a combination of Vault Lake's yedoma environment containing more biolabile OM derived from yedoma permafrost thawing along lake margins as well as potentially higher rates of Holocene-aged organic matter loading to Vault Lake resulting from thermokarst expansion and high primary production in and around the lake enhanced by nutrients released from thawing yedoma (Walter Anthony et al., 2014).

It is interesting to note that studies of deep permafrost (non-lake) sediments found that (a) no $\mathrm{CH}_{4}$ was produced (Wagner et al., 2007; this study), (b) $\mathrm{CH}_{4}$ production rates were an order of magnitude lower (Lee et al., 2012), or (c) $\mathrm{CH}_{4}$ production was only observed after a significant lag time (Knoblauch et al., 2013). In contrast, in studies of shallow-permafrost sediments, $\mathrm{CH}_{4}$ production potentials were observed in anaerobic incubations (Knoblauch et al., 2013; Lee et al., 2012; Waldrop et al., 2010; Wagner et al., 2007). We suggest a potential explanation for these observations in the following section.

\subsection{Role of modern methanogens in $\mathrm{CH}_{4}$ production from old $\mathrm{C}$}

The quantity of methanogens preexisting in soil samples can influence the rate of methanogenesis in laboratory experiments (Gutknecht et al., 2006; Yavitt et al., 2000). In our study, all samples collected from the Vault Lake core produced $\mathrm{CH}_{4}$ within 60 days of incubation, including the Transitional permafrost samples at the bottom of the lake core. In contrast, no samples collected from the Vault Creek permafrost tunnel had detectable $\mathrm{CH}_{4}$ production during the observed 220 days of incubation. A possible explanation for the lack of detectable $\mathrm{CH}_{4}$ production in the permafrost tunnel could be a paucity of viable methanogens naturally present in deep permafrost soils (Wagner et al., 2007; Steven et al., 2006; Gilichinsky et al., 2003; Rivkina et al., 1998). In previous anaerobic incubations of deep permafrost, little or no $\mathrm{CH}_{4}$ production has been observed and there was either no observed $\mathrm{CH}_{4}$ production (non-yedoma permafrost; Wagner et al., 2007), a significant delay before detectable $\mathrm{CH}_{4}$ production occurred (yedoma permafrost; Knoblauch et al., 2013), or no $\mathrm{CH}_{4}$ production until samples were inoculated with modern lake sediments (yedoma permafrost; Walter et al., 2007; S. Zimov, personal communication, 2002). Since we observed $\mathrm{CH}_{4}$ production in the Transitional permafrost (thawing yedoma) beneath Vault Lake but no $\mathrm{CH}_{4}$ production in the permafrost tunnel samples (yedoma and underlying gravel horizons) it is possible that, in thermokarst lake environments, $\mathrm{CH}_{4}$ produced from yedoma $\mathrm{OM}$ requires the reproduction of modern and/or ancient microbes along a thermally expanding substrate source as permafrost thaws radially beneath lakes. 


\section{Conclusions}

Our study suggests that in the center of a first-generation thermokarst lake, whole-column $\mathrm{CH}_{4}$ production is dominated by methanogenesis in the Organic-rich mud facies; however, it is likely that other facies contribute significantly more to $\mathrm{CH}_{4}$ production along laterally expanding thermokarst lake margins. Variability in permafrost $\mathrm{C}$ source, quality, and biodegradability remain significant uncertainties in estimating how thawing permafrost $\mathrm{OC}$ will be processed. Labile fractions of $\mathrm{OC}$ seem to be more absent in nearsurface portions of the taberite, reducing $\mathrm{CH}_{4}$ production rates compared to the underlying Recently thawed taberite along the permafrost thaw boundary. The rapid depletion of the most labile OC pools suggests OC quality may be a limiting factor in determining how thawing permafrost $\mathrm{C}$ is processed in a thermokarst lake environment. The knowledge as to where $\mathrm{CH}_{4}$ originates and what proportion of produced $\mathrm{CH}_{4}$ is emitted will aid in estimations of how $\mathrm{C}$ release and processing in a thermokarst lake environment differs from other thawing permafrost and non-permafrost environments.

\section{The Supplement related to this article is available online at doi:10.5194/bg-12-4317-2015-supplement.}

Author contributions. K. M. Walter Anthony devised the study. J. K. Heslop and K. M. Walter Anthony were responsible for data analysis and writing the paper. K. M. Walter Anthony, J. K. Heslop, G. Grosse, and A. Bondurant conducted field work. J. K. Heslop, A. Sepulveda-Jauregui, K. Martinez-Cruz, and K. M. Walter Anthony performed lab work. M. C. Jones performed macrofossil analysis. All authors commented on data analyses and manuscript composition.

Acknowledgements. We would like to thank P. Anthony, N. Bigelow, S. Billings, N. Haubenstock, T. Howe, and L. Oliver for assistance in data collection and/or analysis and Sam Skidmore for granting access to Vault Lake and the Vault Creek permafrost tunnel. The Spring 2014 Biology 604 class at the University of Alaska, Fairbanks, Vladimir Romanovsky, and Mingchu Zhang provided invaluable guidance and feedback in the preparation of this manuscript. Funding for J. K. Heslop, K. M. Walter Anthony, A. Sepulveda-Jauregui, G. Grosse, and A. Bondurant was provided by DOE DE-SC0006920, NSF OPP-1107892, and ARC-1304823; funding for K. Martinez-Cruz was provided by Conacyt 330197/233369; and funding for M. C. Jones was provided by the USGS Climate and Land Use Research and Development program. This publication was developed under STAR Fellowship Assistance agreement no. FP-91762901-0 awarded by the US Environmental Protection Agency (EPA). It has not been formally reviewed by EPA. The views expressed in this publication are solely those of J. Heslop, and the EPA does not endorse any products or commercial services mentioned in this publication.

Edited by: J. Vonk

\section{References}

Bastviken, D., Cole, J. J., Pace, M. L., and Van de Bogert, M. C.: Fates of methane from different lake habitats: connecting wholelake budgets and $\mathrm{CH}_{4}$ emissions, J. Geophys. Res., 113, G02024, doi:10.1029/2007JG000608, 2008.

Bastviken, D., Tranvik, L. J., Downing, J. A., Crill, P. M., and Enrich-Prast, A.: Freshwater methane emissions offset the continental carbon sink, Science, 331, 50-50, 2011.

Bergman, I., Lundberg, P., and Nilsson, M.: Microbial carbon mineralisation in an acid surface peat: effects of environmental factors in laboratory incubations, Soil Biol. Biochem., 31, 1867$1877,1999$.

Blazewicz, S. J., Petersen, D. G., Waldrop, M. P., and Firestone, M. K.: Anaerobic oxidation of methane in tropical and boreal soils: ecological significance in terrestrial methane cycling, J. Geophys. Res.-Biogeo., 117, G02033, doi:10.1029/2011JG001864, 2012.

Borrel, G., Jézéquel, D., Biderre-Petit, C., Morel-Desrosiers, N., Moerl, J. P., Peyret, P., Fonty, G., and Lehours, A. C.: Production and consumption of methane in freshwater lake ecosystems, Res. Microbiol., 162, 832-847, 2011.

Brosius, L. S., Walter Anthony, K. M., Grosse, G., Chanton, J. P., Farquharson, L. M., Overduin, P. P., and Meyer, H.: Using the deuterium isotope composition of permafrost meltwater to constrain thermokarst lake contributions to atmospheric $\mathrm{CH}_{4}$ during the last deglaciation, J. Geophys. Res., 117, G01022, doi:10.1029/2011JG001810, 2012.

Burn, C. R.: Lake-bottom thermal regimes, western arctic coast, Canada, Permafrost Periglac., 16, 355-367, 2005.

Cohen, A. S.: Paleolimnology: the History and Evolution of Lake Systems, Oxford University Press, New York, USA, 2003.

Cole, J., Prairie, Y., Caraco, N., McDowell, W., Tranvik, L., Striegl, R., Duarte, C., Kortelainen, P., Downing, J., Middelburg, J., and Melack, J.: Plumbing the global carbon cycle: integrating inland waters into the terrestrial carbon budget, Ecosystems, 10, 172185, 2007.

Deutzmann, J. S. and Schink, B.: Anaerobic oxidation of methane in sediments of Lake Constance, an oligotrophic freshwater lake, Appl. Environ. Microb., 77, 4429-4436, 2011.

Duc, N. T., Crill, P., and Bastviken, D.: Implications of temperature and sediment characteristics on methane formation and oxidation in lake sediments, Biogeochemistry, 100, 185-196, 2010.

Farquharson, L. M., Walter Anthony, K. M., Bigelow, N. H. B., Edwards, M. E., and Grosse, G.: Facies analysis of yedoma thermokarst lakes on the northern Seward Peninsula, Alaska, Sediment. Geol., in review, 2015.

Gilichinsky, D., Rivkina, E., Shcherbakova, V., Laurinavichuis, K., and Tiedje, J.: Supercooled water brines within permafrost - an unknown ecological niche for microorganisms: a model for astrobiology, Astrobiology, 3, 331-341, 2003.

Gorini, L.: Effect of L-cysteine on initiation of anaerobic growth of E. Coli and A. Aerogenes, J. Bacteriol., 82, 305-312, 1961. 
Grosse, G., Jones, B., and Arp, C.: Thermokarst lakes, drainage, and drained basins, in: Treatise on Geomorphology, edited by: Shroder, J. F., Academic Press, San Diego, 325-353, 2013 a.

Grosse, G., Robinson, J. E., Bryant, R., Taylor, M. D., Harper, W., DeMasi, A., Kyker-Snowman, E., Veremeeva, A., Schirrmeister, L., and Harden, J.: Distribution of late Pleistocene ice-rich syngenetic permafrost of the Yedoma Suite in east and central Siberia, Russia, USGS, Reston, VA, 31, 2013b.

Gupta, V., Smemo, K., Yavitt, J., Fowle, D., Branfireun, B., and Basiliko, N.: Stable isotopes reveal widespread anaerobic methane oxidation across latitude and peatland type, Environ. Sci. Technol., 47, 8273-8279, 2013.

Gutknecht, J., Goodman, R., and Balser, T.: Linking soil process and microbial ecology in freshwater wetland ecosystems, Plant Soil, 289, 17-34, 2006.

Harden, J. W., Koven, C. D., Ping, C.-L., Hugelius, G., David McGuire, A., Camill, P., Jorgenson, T., Kuhry, P., Michaelson, G. J., O’Donnell, J. A., Schuur, E. A. G., Tarnocai, C., Johnson, K., and Grosse, G.: Field information links permafrost carbon to physical vulnerabilities of thawing, Geophys. Res. Lett., 39, L15704, doi:10.1029/2012GL051958, 2012.

Hugelius, G., Strauss, J., Zubrzycki, S., Harden, J. W., Schuur, E. A. G., Ping, C.-L., Schirrmeister, L., Grosse, G., Michaelson, G. J., Koven, C. D., O’Donnell, J. A., Elberling, B., Mishra, U., Camill, P., Yu, Z., Palmtag, J., and Kuhry, P.: Estimated stocks of circumpolar permafrost carbon with quantified uncertainty ranges and identified data gaps, Biogeosciences, 11, 6573-6593, doi:10.5194/bg-11-6573-2014, 2014.

Jorgenson, M. T., Harden, J., Kanevskiy, M., O’Donnell, J., Wickland, K., Ewing, S., Manies, K., Zhuang, Q., Shur, Y., Striegl, R., and Koch, J.: Reorganization of vegetation, hydrology and soil carbon after permafrost degradation across heterogeneous boreal landscapes, Environ. Res. Lett., 8, 035017, doi:10.1088/17489326/8/3/035017, 2013.

Kanevskiy, M., Shur, Y., Jorgenson, M. T., and Stephani, E.: Cryostratigraphy of late Pleistocene syngenetic permafrost (yedoma) in northern Alaska, Itkillik River exposure, Quaternary Res., 75, 584-596, 2011.

Kankaala, P., Huotari, J., Peltomaa, E., Saloranta, T., and Ojala, A.: Methanotrophic activity in relation to methane efflux and total heterotrophic bacterial production in a stratified, humic, boreal lake, Limnol. Oceanogr., 51, 1195-1204, 2006.

Kessler, M. A., Plug, L. J., and Walter Anthony, K. M.: Simulating the decadal- to millennial-scale dynamics of morphology and sequestered carbon mineralization of two thermokarst lakes in NW Alaska, J. Geophys. Res., 117, G00M06, doi:10.1029/2011JG001796, 2012.

Kholodov, A. L., Rivkina, E. M., Gilichinsky, D. A., FyodorovDavydov, D. G., Gubin, S. V., Sorokovikov, V. A., Ostroumov, V. E., and Maksimovich, S. V.: Estimation of the organic carbon input into Arctic ocean due to erosion of the East-Siberian seashore, Kriosphera Zemli, 7, 3-12, 2003

Kling, G. W. and Kipphut, G. W.: Arctic lakes and streams as gas conduits to the atmosphere: implications for tundra carbon budgets, Science, 251, 298-301, 1991.

Knoblauch, C., Beer, C., Sosnin, A., Wagner, D., and Preiffer, E.: Predicting long-term carbon mineralization and trace gas production from thawing permafrost of Northeast Siberia, Glob. Change Biol., 19, 1160-1172, 2013.
Lee, H., Schuur, E. A. G., Inglett, K. S., Lavoie, M., and Chanton, J. P.: The rate of permafrost carbon release under aerobic and anaerobic conditions and its potential effects on climate, Glob. Change Biol., 18, 515-527, 2012.

Lofton, D. D., Whalen, S. C., and Hershey, A. E.: Effect of temperature on methane dynamics and evaluation of methane oxidation kinetics in shallow Arctic Alaskan lakes, Hydrobiologia, 721, 209-222, 2014.

McGuire, A. D., Anderson, L. G., Christensen, T. R., Dallimore, S. R., Guo, L., Hayes, D. J., Heimann, M., Loreson, T. D., MacDonald, R. B., and Roulet, N.: Sensitivity of the carbon cycle in the Arctic to climate change, Ecol. Monogr., 79, 523-555, 2009.

Meyer, H., Yoshikawa, K., Schirrmeister, L., and Andreev, A.: The Vault Creek Tunnel (Fairbanks Region, Alaska): A Late Quaternary Palaeoenvironmental Permafrost Record, Ninth International Conference on Permafrost, 1191-1196, University of Alaska Fairbanks, Fairbanks, Alaska, USA, 29 June to 03 July, 2008.

Murton, J. B.: Thermokarst-lake-basin sediments, Tuktoyaktuk Coastlands, western arctic Canada, Sedimentology, 43, 737-760, 1996.

Myhre, G., Shindell, D., Breon, F. M., Collins, W., Fuglestvedt, J., Huang, J., Koch, D., Lamarque, J. F., Lee, D., Mendoza, B., Nakajima, T., Robock, A., Stephens, G., Takemura, T., and Zhang, H.: Anthropogenic and natural radiative forcing, in: Climate Change 2013: The Physical Science Basis, Contribution of Working Group I to the Fifth Assessment Report of the Intergovernmental Panel on Climate Change, Intergovernmental Panel on Climate Change, New York, USA, 659-740, 2013.

Pewe, T. L.: Quaternary geology of Alaska, USGS Numbered Series, Professional Paper 835, US Govt. Print. Off., Washington, DC, USA, 1975.

Pienitz, R., Doran, P. T., and Lamoureux, S. F.: Origin and geomorphology of lakes in the polar regions, in: Polar Lakes and Rivers, edited by: Vincent, W., Oxford University Press, Oxford, 25-41, 2008.

Plug, L. J. and West, J. J.: Thaw lake expansion in a twodimensional coupled model of heat transfer, thaw subsidence, and mass movement, J. Geophys. Res., 114, F01002, doi:10.1029/2006JF000740, 2009.

Reimer, P., Bard, E., Bayliss, A., Beck, J. W., Blackwell, P. G., Ramsey, C. B., Buck, C. E., Cheng, H., Edwards, R. L., Friedrich, M., Grootes, P. M., Guilderson, T. P., Haflidason, H., Hajdas, I., Hatté, C., and Heaton, T. J.: IntCal13 and Marine13 radiocarbon age calibration xurves 0-50000 years cal BP, Radiocarbon, 55, 1869-1887, 2013.

Rivkina, E., Gilichinsky, D., Wagener, S., Tiedje, J., and McGrath, J.: Biogeochemical activity of anaerobic microorganisms from buried permafrost sediments, Geomicrobiol. J., 15, 187-193, 1998.

Romanovsky, V., Smith, S., and Christiansen, H.: Permafrost thermal state in the polar Northern Hemisphere during the International Polar Year 2007-2009: a synthesis, Permafrost Periglac., 11, 137-152, 2010.

Schädel, C., Schuur, E. A. G., Bracho, R., Elberling, B., Knoblauch, C., Lee, H., Luo, Y., Shaver, G. R., and Turetsky, M. R.: Circumpolar assessment of permafrost $\mathrm{C}$ quality and its vulnerability over time using long-term incubation data, Glob. Change Biol., 20, 641-652, 2014. 
Schaefer, K., Lantuit, H., Romanovsky, V. E., Schuur, E. A. G., and Witt, R.: The impact of the permafrost carbon feedback on global climate, Environ. Res. Lett., 9, 085003, doi:10.1088/17489326/9/8/085003, 2014.

Schirrmeister, L., Grosse, G., Wetterich, S., Overduin, P. P., Strauss, J., Schuur, E. A. G., and Hubberten, H.: Fossil organic matter characteristics in permafrost deposits of the northeast Siberian Arctic, J. Geophys. Res., 116, G00M02, doi:10.1029/2011JG001647, 2011.

Schulz, S., Matsuyama, H., and Conrad, R.: Temperature dependence of methane production from different precursors in a profundal sediment (Lake Constance), FEMS Microbiol. Ecol., 22, 207-213, 1997.

Schuur, E. A. G., and Abbott, B.: High risk of permafrost thaw, Nature, 480, 32-33, 2011.

Schuur, E. A. G., Abbott, B. W., Bowden, W. B., Brovkin, V., Camill, P., Canadell, J. G., Chanton, J. P., Chapin III, F. S., Christensen, T. R., Ciais, P., Crosby, B. T., Czimczik, C. I., Grosse, G., Harden, J., Hayes, D. J., Hugelius, G., Jastrow, J. D., Jones, J. B., Kleinen, T., Koven, C. D., Krinner, G., Kuhry, P., Lawrence, D. M., McGuire, A. D., Natali, S. M., O’Donnell, J. A., Ping, C.L., Riley, W. J., Rinke, A., Romanovsky, V. E., Sannel, A. B.K., Schädel, C., Schaefer, K., Sky, J., Subin, Z. M., Tarnocai, C., Turetsky, M. R., Waldrop, M. P., Walter Anthony, K. M., Wickland, K. P., Wilson, C. J., and Zimov, S. A.: Expert assessment of vulnerability of permafrost carbon to climate change, Climatic Change, 119, 359-374, 2013

Sepulveda-Jauregui, A., Walter Anthony, K. M., Martinez-Cruz, K., Greene, S., and Thalasso, F.: Methane and carbon dioxide emissions from 40 lakes along a north-south latitudinal transect in Alaska, Biogeosciences, 12, 3197-3223, doi:10.5194/bg-123197-2015, 2015.

Shaver, G. R., Giblin, A. E., Nadelhoffer, K. J., Thieler, K. K., Downs, M. R., Launder, J. A., and Rastetter, E. B.: Carbon turnover in Alaskan tundra soils: effects of organic matter quality, temperature, moisture and fertilizer, J. Ecol., 94, 740-753, 2006.

Smemo, K. and Yavitt, J.: Evidence for anaerobic $\mathrm{CH}_{4}$ oxidation in freshwater peatlands, Geomicrobiol. J., 24, 583-597, 2007.

Smol, J. P.: Pollution of Lakes and Rivers: a Paleoenvironmental Perspective, 2 Edn., Blackwell Publishing, Oxford, UK, 2008.

Soloviev, P. A.: Thermokarst phenomena and landforms due to frostheaving in central Yakutia, Biuletyn Peryglacjalny, 23, 135155,1973

Steven, B., Léveillé, R., Pollard, W., and Whyte, L.: Microbial ecology and biodiversity in permafrost, Extremophiles, 10, 259-267, 2006.

Strauss, J., Schirrmeister, L., Grosse, G., Wetterich, S., Ulrich, M., Herzschuh, U., and Hubberten, H.: The deep permafrost carbon pool of the Yedoma region in Siberia and Alaska, Geophys. Res. Lett., 40, 6165-6170, 2013.

Tranvik, L., Downing, J., and Cotner, J.: Lakes and reservoirs as regulators of carbon cycling and climate, Limnol. Oceanogr., 54, 2298-2314, 2009.

Valentine, D.: Biogeochemistry and microbial ecology of methane oxidation in anoxic environments: a review, Anton. Leeuw. Int. J. G., 81, 271-282, 2002.
Valentine, D., Holland, E. A., and Schimel, D. S.: Ecosystem and physiological controls over methane production in northern wetlands, J. Geophys. Res.-Atmos., 99, 1563-1571, 1994.

Wagner, D., Gattinger, A., Embacher, A., Pfeiffer, E. M., Schloter, M., and Lipskis, A.: Methanogenic activity and biomass in holocene permafrost deposits of the Lena Delta, Siberian Arctic and its implication for the global methane budget, Glob. Change Biol., 13, 1089-1099, 2007.

Waldrop, M. P., Wickland, K. P., White III, R., Berhe, A. A., Harden, J. W., and Romanovsky, V. E.: Molecular investigations into a globally important carbon pool: permafrost-protected carbon in Alaskan soils, Glob. Change Biol., 16, 2543-2554, 2010.

Wallmann, K., Aloisi, G., Haeckel, M., Obzhirov, A., Pavlova, G., and Tishchenko, P.: Kinetics of organic matter degradation, microbial methane generation, and gas hydrate formation in anoxic marine sediments, Geochim. Cosmochim. Ac., 70, 3905-3927, 2006.

Walter, K. M., Zimov, S. A., Chanton, J. P., Verbyla, D., and Chapin, I. F.S.: Methane bubbling from Siberian thaw lakes as a positive feedback to climate warming, Nature, 443, 71-75, 2006.

Walter, K. M., Smith, L. C., and Chapin, F. S.: Methane bubbling from northern lakes: present and future contributions to the global methane budget, Philos. T. R. Soc. A, 365, 1657-1676, 2007.

Walter, K. M., Chanton, J. P., Chapin, F. S., Schuur, E. A. G., and Zimov, S. A.: Methane production and bubble emissions from arctic lakes: Isotopic implications for source pathways and ages, J. Geophys. Res., 113, G00A08, doi:10.1029/2007JG000569, 2008.

Walter Anthony, K. M. and Anthony, P.: Constraining spatial variability of methane ebullition seeps in thermokarst lakes using point process models, J. Geophys. Res.-Biogeo., 118, 10151034, 2013.

Walter Anthony, K. M., Zimov, S. A., Grosse, G., Jones, M. C., Anthony, P. M., Chapin III, F. S., Finlay, J. C., Mack, M. C., Davydov, S., Frenzel, P., and Frolking, S.: A shift of thermokarst lakes from carbon sources to sinks during the Holocene epoch, Nature, 511, 452-456, 2014.

Westermann, P.: Temperature regulation of methanogenesis in wetlands, Chemosphere, 26, 321-328, 1993.

Wetzel, R. G.: Limnology: Lake and River Ecosystems, 3rd Edn., Elsevier Academic Press, San Diego, CA, 2001.

Williams, P. J. and Smith, M. W.: The Frozen Earth: Fundamentals of Geocryology, Cambridge University Press, Cambridge, UK, 1989.

Wright, E. L., Black, C. R., Cheesman, A. W., Drage, T., Large, D., Turner, B. L., and Sjögersten, S.: Contribution of subsurface peat to $\mathrm{CO}_{2}$ and $\mathrm{CH}_{4}$ fluxes in a neotropical peatland, Glob. Change Biol., 17, 2867-2881, 2011.

Yavitt, J. B., Williams, C. J., and Wieder, R. K.: Controls on microbial production of methane and carbon dioxide in three sphagnum-dominated peatland ecosystems as revealed by a reciprocal field peat transplant experiment, Geomicrobiol. J., 17, 61-88, 2000.

Yavitt, J. B., Williams, C. J., and Wieder, R. K.: Soil chemistry versus environmental controls on production of $\mathrm{CH}_{4}$ and $\mathrm{CO}_{2}$ in northern peatlands, Eur. J. Soil Sci., 56, 169-178, 2005.

Yvon-Durocher, G. A., Bastviken, A. P., Conrad, D., Gudasz, R., St-Pierre, C., Thanh-Duc, A., Giorgio, N., and Paul, A.: Methane 
fluxes show consistent temperature dependence across microbial to ecosystem scales, Nature, 507, 488-491, 2014.

Zimov, S. A., Voropaev, Y. V., Semiletov, I. P., Davidov, S. P., Prosiannikov, S. F., Chapin, F. S., Chapin, M. C., Trumbore, S., and Tyler, S.: North Siberian lakes: a methane source fueled by pleistocene carbon, Science, 277, 800-802, 1997.
Zimov, S. A., Schuur, E. A. G., and Chapin, F. S.: Permafrost and the global carbon budget, Science, 312, 1612-1613, 2006. 